\title{
FIXAÇÃO DE FÓSFORO EM SOLOS QUE RECEBERAM QUANTIDADES VARIÁVEIS DAS ARGILAS VERMICULITA E CAULINITA
}

FRANCISCO AUGUSTO MORA SOLÍS

Orientador: Prof. Dr. RONALDO IVAN SILVEIRA

Dissertação apresentada à Escola Superior de Agricultura "Luiz de Queiroz", da Universidade de São Paulo, para obtenção do título de Mestre em Solos $\theta$ Nutrição de Plantas.

PIRACICABA

Estado de São Paulo - Brasil

Outubro - 1981 


\section{A GRADEC IMENTOS}

Ao Professor Dr. Ronaldo. I van Silveira., pela orientação e o apoio prestado na reàlização deste trabalho.

Aos Professores Dr. Josē Renato Sarruge e Dr. Toshiaki Kinjo, pelas sugestões dadas.

Aos Professores or. Josē Luiz Ioriatti Demattē e Antonio Car los Teixeira Mendes, pela colaboração nas anāiises mineralógicas das amostras.

Ao Professor Dr. Zilmar Ziller Marcos, pela versão do resumo do trabalho para o inglès.

Aos Senhores funcionärios do Departamento de Solos, Geologia e Fertilizantes da E.S.A. "Luiz de Queiroz", pela colabora çăo nas anălises físicas e químicas das amostras.

Aos Senhores funcionārios da Biblioteca da E.S.A. "Luiz de Queiroz", pela ajuda prestada.

A Senhora Nelci Teixeira Maniero, pelos serviços datilográfi cos.

A Organização dos Estados Americanos (O.E.A.)., pela conces são da bolsa de estudo durante o curso.

A Escola Superior de Agricultura "Luiz de Queiroz", por todas as facilidades oferecidas no desenvolvimento de meus es tudos. 
2.1. Aspectos gerais sobre o problema da fixa -

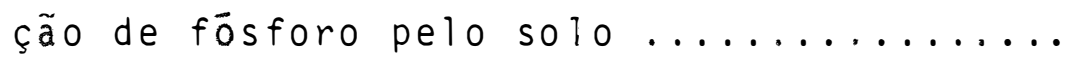

2.2. Natureza dos compostos do solo e dos fatores envolvidos na fixação do fösforo ..... 6 2.2.1. Influência das argilas silicatadas.

2.2.2. Influência dos óxidos e hidrōxidos de ferro e aluminio .............

2.2.3. Influência dos cātions trocāveis...

2.2.5. Influência do tempo de contato entre o ion fosfato e o solo ..........

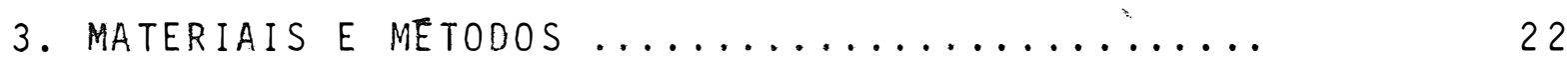

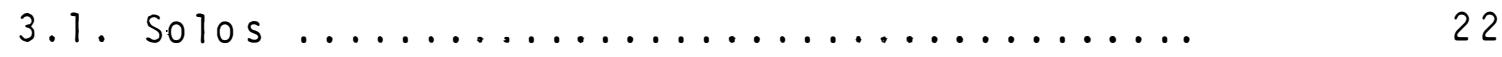

3.2. Determinação das características físicas e

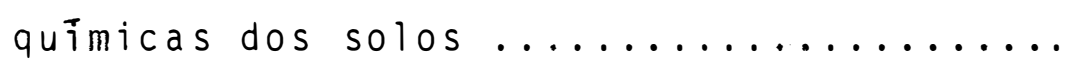

3.2.1. Métodos analiticos utilizados nas determinações das características físicas e químicas das amostras ... 
i i i.

Pàgina

3.2.1.1. Anālise granulomētrica ...

3.2.1.2. Anālise química de fertili dade das amostras .......

3.2.1.3. Determinação dos óxidos de ferro livre ..........

3.2.1.4. Determinação do fósforo tọ ta $\ldots \ldots \ldots \ldots \ldots$

3.3. Anālise minerăōgica da fração argila ....

3.3.1. Reconhecimento dos minerais de argi

la $\ldots \ldots \ldots \ldots \ldots \ldots \ldots \ldots$

3.4. Determinação da capacidade de fixação de

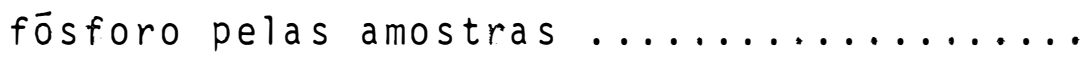

4. RESULTADOS E DISCUSSAO $\ldots \ldots \ldots \ldots \ldots$

4.1. Efeito na fixação de fósforo causado por doses crescentes de minērio vermiculitico nas amostras de terra dos solos Paredão

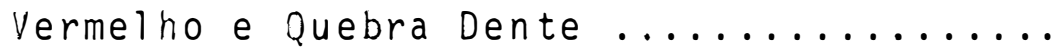

4.1.1. Influência do teor e da natureza da

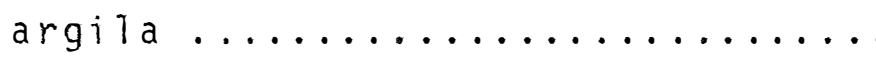

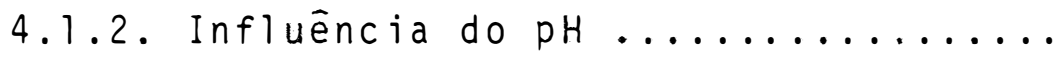

4.1.3. Influência do ferro e alumīnio trocáveis e dos óxidos e hidrōxidos de

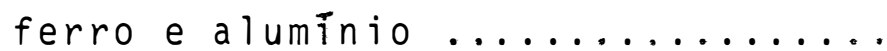


pāgina

4.1.4. Influência do cálcio e magnésio tro càveis $\ldots \ldots \ldots \ldots \ldots \ldots \ldots \ldots$

4.1.5. Influéncia da capacidade de troca de cátions e da porcentagem de satu

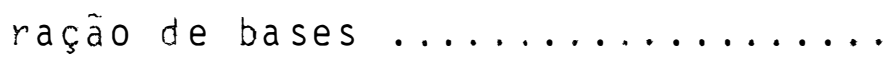

4.1.6. Influência do teor de areia ......

4.2. Efeito na fixação de fósforo causado por doses crescentes de minērio caulinitico nas amostras de terra dos solos paredão

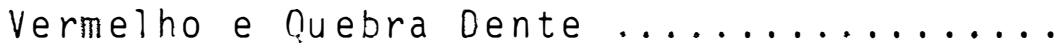
4.2.1. Influéncia das características edá-

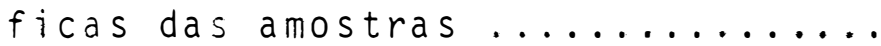

4.3. Efeito do tempo de contato entre o ion fos fato e o solo na fixaçäo de fösforo ......

4.4. Efeito na fixaçäo de fósforo causado pela quantidade de fosfato aplicado ..........

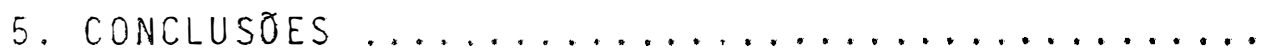

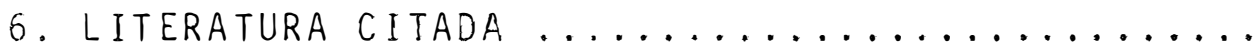


1 - Localização e classificação dos solos a nĩvel de Sërie e de Grande Grupo .............. 23

2 - Quantidades de solo e minērio vermiculitico e

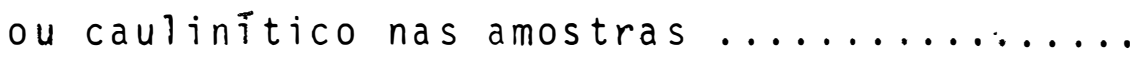

3 - Anālise granulométrica das amostras .........

4 - Caracteristicas quimicas das amostras de solos

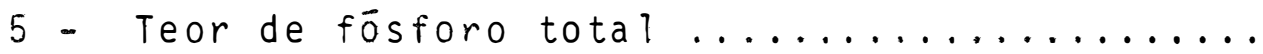

6 - Alguns minerais de argila e seus espaçamentos basais respectivos $\ldots \ldots \ldots \ldots \ldots \ldots \ldots$

7 - Anälise mineralögica da fração argila das amos

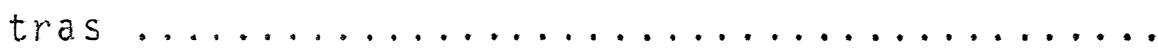

8 - Resultados do ensaio de fixação de fósforo obtidos da incubação do solo Paredão Vermelho e quantidades variāveis de minērio vermiculītico com dois niveis de fósforo aos 10 e 20 dias..

9 - Resultados do ensaio de fixação de fósforo obtidos da incubação do solo Quebra Dente e quạ tidades variā̄eis de minērio vermiculitico com dois níveis de fósforo aos 10 e 20 dias ...... 
10 - Anāilise de variāncia para a porcentagem de $r$ fixado pelas amostras com doses crescentes

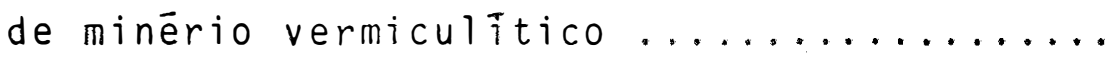

11 - Resultados do ensaio de fixação de fōsforo obtidos da incubação do solo Paredão Verme Tho e quantidades variāveis de minērio cauli nîtico com dois niveis de fósforo aos 10 e 20 dias $\ldots \ldots \ldots \ldots \ldots \ldots \ldots \ldots \ldots \ldots \ldots \ldots \ldots$

12 - Resultados do ensaio de fixação de fósforo obtidos da incubação do solo Quebra Dente e quantidades variāveis de minērio caulinitico com dois nỉveis de fósforo aos 10 e 20 dias.

13 - Anāilise de variància para a porcentagem de $P$ fixado pelas amostras com doses crescentes

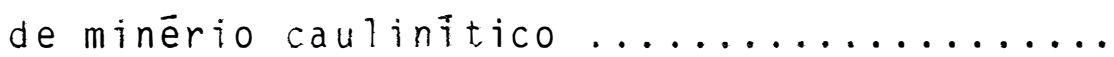

14 - Porcentagens relativas da quantidade de $P$ f xada pelos tratamentos aos 10 dias de incuba f̧ão quando comparadas com tratamentos cor respondentes aos. 20 dias de incubação, desig nados como indice $100 \ldots \ldots \ldots \ldots$ 
1 - Difratogramas de raıo-x da fração argila da amostra 01 horizonte Ap do solo Paredào Vermelho) $\ldots \ldots \ldots \ldots \ldots \ldots \ldots$

2 - Difratogramas de raio-X da fraçăo argila da amostra 09 (minério vermiculitico) .......

3 - Difratogramas de raio-X da fraçào argila da amostra 17 (minērio caulinitico) ........

4 - Difratogramas de raio-X da fração argila da amostra 18 (horizonte Ap do solo Quebra Den

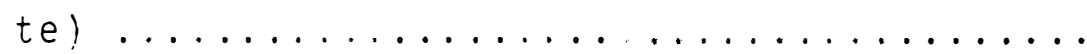

5 - Curvas de fixação de p para o solo paredão Vermelho com doses variāveis de minério ver miculitico $\ldots \ldots \ldots \ldots \ldots \ldots \ldots \ldots \ldots$

6 - Curvas de fixação de P para o solo Quebra Dente com doses variāveis de minērio vermi-

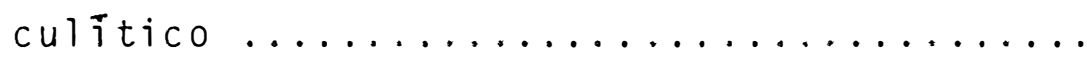

7 - Curvas de fixação de P para o solo paredão Vermelho com doses variāveis de minério cau

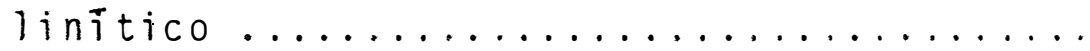


viii.

Pägina

8 - Curvas de fixação de p para o solo quebra Dente com doses variāveis de minērio cau$\operatorname{linitico} \ldots \ldots \ldots \ldots \ldots \ldots \ldots$ 
FIXAÇAO DE FOSFORO EM SOLOS QUE RECEBERAM QUANTIDADES VARIAVEIS DAS ARGILAS VERMICULITA E CAULINITA.

Candidato: Francisco Augusto Mora Solis

Orientador: Prof.or. Ronaldo Ivan Silveira

\section{RESUMO}

Utilizando um minērio vermiculitico e outro cauli nĩtico, determinou-se a influēncia das argilas vermiculita e caulinita na capacidade de fixaçăo de fósforo de um solo podzō lico e de um Latossol, ambos de textura arenosa, provenientes do Municipio de Piracicaba.

0 experimento foi conduzido em laboratōrio. Amostras de terra,coletadas no horizonte Ap dos solos foram misturadas com quantidades crescentes das argilas que variaram entre 1,25 e 25,0 por cento emi peso, e incubadas durante perío dos de 10 e 20 dias com doses de 50 e 100 ppm de $P$ no solo.

Foi feita, preliminarmente, a anālise mineralōgica dos minērios e dos solos, e das características químicas e granulomētricas de todas as amostras. 
os resultados da porcentagem de fósforo fixado pelos tratamentos se analisaram estatisticamente e se fizeram correlações lineares simples com algumas das características edäficas das amostras.

As seguintes conclusöes foram obtidas:

1. O minério vermiculítico e o solo Quebra Dente (Podzōiico), apresentaram uma maior capacidade de fixação de fósforo do que o minério caulinítico e que o solo paredão Vermelho (Latossol), respectivamente.

2. A porcentagem de fósforo fixada pelos solos aumentou com o acréscimo do porcentual do minërio vermiculíti co, até adquirir valores pröximos à porcentagem fixada pelo minērio puro. Atribuiu-se este aumento da fixação do fósforo à natureza da argila adicionada (vermiculita) e a alta concen traçăo de magnésio numa faixa de pH favorāvel à precipitação de compostos fosfatos-magnesianos.

3. O efeito das doses crescentes de caulinita aplicadas foi conträrio nos dois solos: aumentou a porcenta gem de fósforo fixado no solo Paredão Vermelho e a diminuiu no solo Quebra Dente.. No primeiro solo citado, o aumento possivelmente esteve relacionado com o acréscimo do teor de argi la, e com a natureza da caulinita que apresenta cargas eletro 
positivas na faixa de pH dos tratamentos. No segundo caso, a diminuição do fósforo fixado nos tratamentos com o solo Quebra Dente pode ser atribuỉdo a um efeito de diluição da concentração da ilita e da vermiculita nativa.

4. Em todos os tratamentos, a quantidade e a por centagem de fósforo fixada aumentou com o tempo de contato amostra-fósforo. Cerca de $90 \%$ ou mais da fixação ocorreu aos 10 dias de incubação, o que mostra que o processo se estabilizou entre os periodos estudados de 10 dias e 20 dias.

5. Dentro de um mesmo tempo de incubação 110 ou 20 dias) a quantidade, em ppm, de fósforo fixado, aumentou com a dose de fósforo aplicado (50 e $110 \mathrm{ppm})$, mas o porcentual fixado diminuiu, indicando a saturação das amostras com o ion fosfato. 


\section{PHOSPHORUS FIXATION IN SOILS TO WHICH VARYING QUANTITIES} OF VERMICULITE AND KAOLINITE CLAY WERE ADDED.

Candidate: Francisco Augusto Mora Solis

Adviser: Prof.Dr. Ronaldo Ivan Silveira

SUMMARY

Vermiculitic and kaolinitic materials were used to determine the effect of these clay minerals on the phosphorus fixing capacity of two sandy soils, a Podzolic and a Latosol, both occurring in the Piracicaba municipality.

Quantities varying from $1.25 \%$ to $25 \%$ (weight basis) were throughly mixed with samples taken from the Ap horizon of the two soils. Two groups of treatments thus prepared received an application of soluble phosphorus at the rate of 50 and $100 \mathrm{ppm}$, and were incubated for two different periods, 10 and 20 days.

The clayey materials and soils were analized as to their mineralogical characteristics. The chemical characte ristics and particle size distribution of the samples were also de termined. 
The results obtained were statistically analyzed. The following condusions were drawn:

1. The vermiculitic material and the Podzolic soil had a greater phosphorus fixing capacity than the kaolini tic material. and the Latosol soil, respectively.

\section{Percentage of phosphorus fixed by the soils} increased with the percentage of vermiculite approaching the fixing capacity of the pure clay-mineral. This effect was attributed to the nature of the clay (vermiculite) and to a high magnesium concentration in a pH range favorable to the precipitation of phospho-magnesium compounds.

3. The addition of increasing quantities of kaolinite had opposite effects in the soils studied: it caused an increased in the \% of fixed phosphorus in the Podzolic soil and a decrease in the Latosol. For the Latosol, this effect is possibly related to the increase in clay content and to the na ture of kaolinite whicil exhibits positive charges in the pH ran ge of the treatments. As for the Podzolic the effect observed may be attributed to the resulting dilution of native illite and vermiculite clays.. 
4. Amount and percentage of fixed phosphorus increased with time of incubation for all treatments, but approximately $90 \%$ or more of total p fixation occurred after 10 days, indicating that the phosphorus fixing processes stabilized between 10 and 20 days of incubation.

5. For a given incubation period (10 or 20 days) the amount of phosphorus fixed (ppm) increased with rate of $p$ added, but the $\%$ of phosphorus fixed decreased, indicating that the samples were probably saturated with the phosphate ion. 


\section{INTRODUÇAO}

0 fósforo è olemento que mais frequentemente limita as produções agricolas nas regiões de clima tropical e sub-tropical, sendo que seu conteúdo total no solo atinge em média $0,1 \%$ de fósforo. E a maioria dos solos tem dificuldade em transformar essa pequena quantidade, em formas disponíveis às plantas. Pesquisas conduzidas em solos do Brasil, especificamente em solos sob vegetação de cerrado, têm comprovado sua extrema pobreza em nutrientes, dos quais o fósforo é considera do o macronutriente essencial na fertilização.

A ocorrēncia de vermiculita com fosfatos, em jazidas prōximas ou simultāneas, assim como a presença de outras fontes de argilas no Brasil, a caulinita por exemplo, pode ser utilizada no melhoramento dos solos arenosos, pobres em fósforo, modificando as suas condições físicas e químicas. 
Considerando a possivel utilização de minērios que contem argila, para melhorar a capacidade de retenção de nutrientes pelos solos, realizaou-se, o presente trabalho em condições de laboratório, com o objetivo de estudar:

1. O efeito na fixação de fósforo causado por do ses crescentes de argila no solo;

2. A diferença de comportamento entre a vermiculita e a caulinita no processo de fixação;

3. A influência do tempo de contato entre o ion fosfato e o solo no fenōmeno da fixação;

4. O efeito da dose de fosfato adicionada na quantidade e na porcentagem do fósforo fixado. 
2.1. Aspectos gerais sobre o problema da fixação de fósforo. pelo solo

A fixação de fósforo pelos solos jā era estudada desde o século passado, quando Way em 1850, citado por VElAYuTHAM (1980), demonstrou que parte do fosfato era retido quando soluções de fosfato de sōdio em āgua ou de guano em ácido sulfúrico diluīdo se vertiam sobre uma camada de solo calcário.Des de então, sinōnimos como fixação de fosfato, sorção de fosfato, retenção de fosfato e reversão de fosfato tem sido usados na 7 iteratura da ciência do solo para descrever este processo.

Igualmente remota é a preocupação sobre a forma e os compostos formados na fixação do fósforo.

Segundo KARDOS (1969), a fixação dos nutrientes das plantas pelo solo, pode ser definida genericamente como o 
processo pelo qual os nutrientes, prontamente solúveis, são transformados em formas menos solūveis, por reações com compos tos orgânicos ou inorgãnicos do solo, resultando uma restrição na mobilidade dos nutrientes ou decréscimo na sua assimilidade pela planta. Para CATANI e PELLEGRINO (1960), qualquer fenômeno que determine uma diminuição na concentração do íon ortofos fato de uma solução em contato com o solo é responsável pela fixação de fōsforo.

Dois métodos tem sido usados amplamente nos es tu dos de fixação do fósforo: (1) medições do decréscimo de concentração das soluções aquosas de fosfato apōs o contato com os solos e (2) medições da diferença de fösforo extraĩvel (por plantas ou reagentes) de um solo tratado com compostos fosfata dos, comparado com o solo não tratado. Medições da penetração do fosfato nos solos também tem sido usadas como um índice da fixação.

Extensas revisões criticas foram apresentadas por: DAVIS (1935); DEAN (1949); WILD (1950); KURTZ (1953); OLSEN (1953); HENWALL (1957); LARSEN (1967) estabelecendo os con ceitos, importância e interpretação físico-química da fixação do ion fosfato pelos solos, sejam estes ácidos, neutros ou alcalinos. No Brasil, diversos pesquisadores tem-se preocupado com o problema, podendo mencionar entre outros: CATAN (1947); MALAVOLTA e PELEGRINO (1954); CATANI e GLORIA (1964) e MELLO (1970). 
De uma maneira geral, apesar dos principais cons tituintes responsáveis pela retenção de fósforo nos solos tropicais terem sido estabelecidos, ainda värias dúvidas persis tem quanto ao tipo de interação predominante, a qual tambēm é responsāvel pela posterior liberação do elemento para a solu ção do solo.

HEMWALL (1957), julgou que a fixação de fósforo no solo, tanto pode ocorrer por precipitação como por adsorção, dependendo das condições existentes no solo. Esta fixação é de vida à formação de compostos de ferro e aluminio do tipo $\mathrm{M}\left(\mathrm{H}_{2} \mathrm{O}\right)_{3}(\mathrm{OH})_{2} \mathrm{H}_{2} \mathrm{PO}_{4}$ (M representa um cátion de ferro ou aluminio) que podem precipitar ou ser adsorvidos no solo.

HSU (1965), afirma que a natureza da fixação ē a inda confusa, sendo-l he atribuida diversas causas ligadas ora a fenōmenos químicos e ora a fenōmenos físicos de adsorção. Es tudando a fixação de fosfato em solos ácidos, informa que a a d sorção física não poderá ser considerada como um processo de fixação de certa importância. Acrescenta, que a adsorção e pre cipitação resultam do mesmo tipo de força quîmica, dependendo ambos do aluminio e/ou do ferro presentes no momento da reação e por sua vez, são dependentes do pH e da concentração da solü ção do fosfato. 
A ligação do fósforo com os componentes dos solos pode-se dar através de processos de adsorção, precipitação, troca ionnica ou troca isomórfica (DUNBAR e BAKER, 1965). Evi dentemente, dependendo das condições locais, algumas interações ocorrem com maior intensidade, enquanto que outras. se con duzem lentamente.

FASSBENDER (1966), sugeriu que no solo ocorrem dois tipos de reação dos fosfatos:

- o primeiro tipo, são as reações que obedecem os principios físico-químicos, como a lei das massas. São reações de precipitação do fósforo em precipitados de baixa solubilidade e de fosfatos complexos, cristalinos ou amorfos;

- o segundo tipo de reação obedece leis específi cas químico-coloidais, e ocorre na adsorção do fósforo pelas particulas coloidais como matéria orgānica, argilas e hidróxidos.

2.2. Natureza dos compostos do solo e dos fatores envolvidos na fixação do fósforo.

Tem sido admitido que a fixação de fosfato estā relacionada com diversos constituintes dos solos. Consequentemente vārias reações de fixação podem ocorrer ou näo ao mesmo 
tempo, dependendo dos teores relativos desses constituintes e das características dos solos.

A presença de $\mathrm{Ca}^{+2}, \mathrm{Fe}^{+3}, \mathrm{Al}^{+3}, \mathrm{Mg}^{+2}, \mathrm{~K}^{+}, \mathrm{H}^{+} \mathrm{e}$ $F^{-}$constitui, segundo LINDSAY e MORENO (1960), independente mente da fase do solo em que se encontrem, uma influéncia cons tante na disponibilidade do ion fosfato. Coube a esses autores relacionar a atividade de cada um desses fons com a estabilida de dos respectivos compostos encontrados na fase sōlida. Para eles, o produto das reações que ocorrem poderā ser ou não precipitado segundo a concentração de tais ĩons na solução do so10.

CLARK e PEECH (1960), estudando a influēncia de sais neutros na concentração do ion fosfato na solução, observaram que o produto da atividade iōnica envolvendo $\mathrm{H}^{+}, \mathrm{K}^{+}$e $\mathrm{Ca}^{+2}$ e $\mathrm{H}_{2} \mathrm{PO}_{4}^{-}$permanecia constante em diferentes concentraçães de eletrólitos, e atribuem o fato à possibilidade do íon fosfa to ser co-adsorvido com os cātions trocáveis nas partículas do solo

Na avaliação da capacidade de fixação de $p$ por solos do Estado de São Paulo, CATANI e PELLEgRINo (1960), salientaram que as quantidades de fósforo fixadas pelos solos de pendiam da concentração do elemento na solução, pH da solução, tempo de reação, temperatura e relação peso:volume entre o so10 e a solução. 
Conforme TISDALE e NELSON (1965), os principais fatores que afetam a fixação de fósforo são os seguintes: tipo de mineral de argila, tempo de reação, pH, temperatura, matē ria orgānica, saturação de fósforo no solo e relação $R_{2} O_{3} / P_{2} O_{5}$.

Atravës de correlações lineares entre as caracte rísticas do solo ( $\mathrm{pH}$, porcentagem de argila, porcentagem de car bono, ōxidos de ferro livres, alumínio trocāvel) e a porcentagem de fósforo fixado, FASSBENDER (1969b), enciontrou que os va lores mais elevados da correlaçăo foram obtidos quando se relacionaram as porcentagens de fixação com as de argila, ferro, alumínio, carbono e indice pH, respectivamente.

\subsubsection{Infiuência das argilas silicatadas}

Um grande nümero de trabainos tem mostrado a influéncia significativa do teor de argila na fixação de fosfato (CATANI e PELLEGRINO, 1957; HEMWALL, 1957; OLSEN e WATANABE, 1957; FRANKLIN e RETSENAUER, 1960; LEAL et a 7 ii, 1973).

Estudando o mecanismo da adsorção de fosfato pelas argilas caulinita, haloisita e bentonita, STOUT (1939), con cluiu que o fenómeno se deve a uma troca reversivel entre os ions fosfatos e as oxidrilas da rede cristalina. Observou, tam bém, que a caulinita e a haloisita adsorveram mais fósforo que 
a bentonita, como consequéncia do maior número de oxidrilas disponiveis na superficie das duas primeiras.

HASEMAN (1950), observou que a fixação de fósfọ ro pelas argilas, caulinita, ilita e montmorilonita aumentou com a elevação da temperatura, concentração do fosfato na solução do meio e com a diminuição do pH. Um resultado discordan te foi encontrado por HALL e BAKER (1971), ao constatar que a montmorilonita contribui para aumentar a quantidade de fósforo fixado quando o pH se eleva. Porēm, DE DATTA (1961), pesqui sando a fixação de fósforo pela montmorilonita (bentonita Kas himir, India), saturada com hidrogênio, verificou que a reten ção diminui com o aumento do pH da solução fosfatada. Conclui que a fixação de fósforo tanto foi devida à associação deste com as argilas, por forças físicas, como à formação de fosfatos insolúveis com o aluminio removido da rede cristalina.

KITTRICK e JACKSON (1955) com o uso do microscópio eletrónico, observaram que a caulinita e a grenalita (silicato hidratado de ferro, com estrutura parecida a da caulinita) reagem com o fosfato originando uma nova fase de fosfato cristalino. Utilizando também fotografias tomadas a o microscópio eletrónico, onde partículas de caulinita, previamen te impregnadas com pirofosfato são incapazes de adsorverem ou ro finamente dispersas nas suas arestas, MARSHALL (1964), sugere que ocorrem dois tipos de adsorção das partículas pelo 
colóide: adsorção na superfície plana e nas arestas dos mine rais, ocorrendo principalmente no seguinte caso, conforme 0 observado. Admite o autor que o ätomo de fōsforo, pelas suas dimensões, pode-se acomodar na estrutura do tetraedro de sili ca com aumento da carga negativa da argila.

OLSEN e WATANABE (1957), verificaram que, dentro da fração de argila, a adsorçäo do fosfato foi proporciona? à superfície especifica e que os solos äcidos retiveram mais fös foro e com maior energia.

CATANI e PELLEGRINO (1960), em um estudo da capa cidade de fixação de fósforo de quinze solos do Estado de São Paulo, encontraram que o solo que mais fósforo fixou; apresentou o menor pH, o menor indice de saturação de bases e a maior porcentagem de argila; o menor valor para a fixação foi determinado para um so ?o muito ácido, com baixa saturação de bases e com baixa porcentagem de argila.

ANASTACIO (1968), trabalhando sobre a capacidade de fixação de fosfatos pelos solos brasileiros, determinou que o teor de argila tem uma influência relativa na fixação de fós foro: os latossolos que retiveram menos fösforo, com 20 e $18 \%$ de fixação tem um teor de argila de 22 e $15 \%$ respectivamente, no entanto, o podzölico que retem mais fósforo, $52 \%$, tem $33 \%$ de argila. 
2.2.2. Influência dos óxidos e hidróxidos de ferro e a 1 uminio

Muitos autores têm encontrado uma relação muito estreita entre o conteúdo de óxidos e hidróxidos de ferro e aluminio no solo e a capacidade de fixação de fosfatos. Com respeito à eficiência relativa do ferro ou do aluminio no pro cesso de fixação, alguns pesquisadores tem considerado que o ferro é um agente mais poderoso que o aluminio, embora, o con trārio tambēm tem sido argumentado.

WEISER e FORD (1933) mostraram que goethita,bau xita e limonita, mas não hematita fixavam fosfato. KITTRICK e JACKSON (1955) observaram no microscópio eletrónico a forma ção de uma fase separada de cristais de fosfato quando colóides de óxido de ferro e hidróxidos de aluminio foram tratados com $\mathrm{KH}_{2} \mathrm{PO}_{4}$. BLANCHET (1959) sugeriu que a precipitação de fósforo por $\mathrm{Fe}(\mathrm{OH})_{3}$ coloidal seguia um mecanismo mais da adsorção do que precipitação. MULJADI et alij. (1966) estudaram a adsorção de fosfato pela caulinita, gibsita e pseudo-bohemi ta e concluiram que a adsorção ocorre sobre as bordas de $\mathrm{Al}(\mathrm{OH})_{2}^{+}$e em outras regiões amorfas.

WILLIAMS (1960), BROMFIELO (1964) e SAINI (1965) concluiram que o aluminio é o constituinte principal de reten- 
ção de fosfatos em solos ácidos. Kaila citado por VELAYUTHAM (1980), encontrou que a variação do conteúdo de aluminio deter minou uma variação de 59 i: na capacidade de fixação de fósforo de solos arenosos e de $70:$ nos solos argilosos. A variação do teor de ferro aumentou essa porcentagem somente de 61 a $78 \%$ respectivamente.

* BitTencourt e Zambello (1973), encontraram valores altamente significativos para as relações entre os teores de argila, porcentagem de ōxido de ferro livre e a adsorção mä xima de fosfato de diversos solos do Estado de São Paulo. Por outro lado, baixos valores foram revelados para as relações entre a adsorçăo de fosfato e os teores de aluminio trocável. Esses dados vem confirmar os obtidos por FASSBENDER (1969a, 1969b), o qual estabeleceu que a fixação de fósforo em solos tropicais é afetada principalmente pe de óxido de ferro livre. O autor concluiu que nos solos brasileiros a imobilização era predominantemente associada com compostos de ferro, enquanto que para os solos da Costa Rica, a retenção pelo alumīnio predominava. Esse mesmo autor, entretan to não encontrou nenhuma associação significativa entre a fixa ção do ànion e os teores de aluminio trocāvel.

Valores discordantes foram obtidos por SYERS et a 1ij (1971), os quais mostraram que as reações de fixação do fósforo estão muito mais ligadas aos hidróxidos de aluminio do 
que ao ferro, apesar da remoção do alumỉnio trocāvel apenás ocasionar um pequeno decrēscimo na retenção do ânion. Sendo que, a remoção do alumīnio e ferro com oxalato, diminuiu a ad sorção de 19 a $100 \%$. Para explicar isto, UDO e UZU (1972), propõem que pode ocorrer um mecanismo de adsorção entre o fós foro e os ions de alumínio ligados à superfície dos minerais de argila ou dos ōxidos ativos. Portanto, este tipo de liga. ção deve apresentar uma maior seletividade pelo fósforo que os outros constituintes fixadores do solo.

VOLK e MCLEAN (1963), aplicaram três nîveis de ${ }^{32} p$ em quatro solos com diferentes graus de retenção de fosfato, e observaram que, em geral, mais de $90 \%$ do fósforo aplica do havia sido imobilizado como fosfatos de aluminio e ferro. Afirmam que esses fosfatos podem ser formados mesmo com pH 7 ou superior.

Em solos levemente äcidos, o fósforo não é fixado na forma de compostos, tais como a variscita e a strengita, e sim, adsorvido a hidróxidos de ferro e aluminio amorfos, hidroxi-polímeros, existentes no solo (HSU, 1964). O autor obser vou que, quando uma solução de fosfato permaneceu por um ano em contato com esse tipo de solo, surgia no sistema uma nova fase formada por hidróxido fërrico, o qual retinha a maior par te do fósforo fixado. 
MOURA FILHO (1970), estudou a retenção de fosfa to em solos brasileiros, em reíação aos compostos da fração argila e concluiu que no solo em estudo, os óxidos de ferro livre eram os principais responsāveis pela adsorção do fósforo. Parte do fósforo estava associado ao cälcio e apenas na fração oclusa aparecia fósforo ígado ao aluminio. o mesmo au tor encontrou aumento da retenção pelo aumento da superficie de reação, sem que, contudo, observasse proporcionalidade entre as duas medidas.

DABIN (1970), observou que os solos ricos em goe ti ta retinham fósforo com mais energia, contra o extrator 01sen, que solos ricos em hematita. Ademais, o autor verificou que, a curto prazo,o fósforo se unia em maior proporção ao alu minio, ao passo que a longo tempo, a participação do ferro era mais importante.

\subsubsection{Influência dos cátions trocāveis}

A eficiência dos cátions na adsorção de fosfato

decresce na ordem: $\mathrm{Ca}>\mathrm{Mg}>\mathrm{H}>\mathrm{NH}_{4}>\mathrm{K}>\mathrm{Na}$, o qual é o con trārio de sua ordem na liberação dos fosfatos adsorvidos (RAVI KOVITCH, 1939). 
HIBBARD (1939), num trabalho em que estudou a fi xação de fósforo em dez solos, verificou que a fixação aumen -

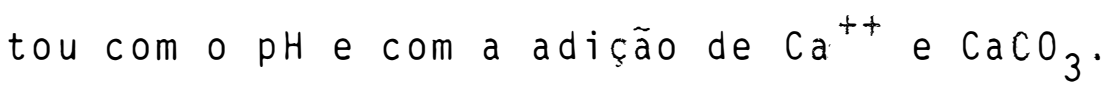

Alguns autores, explicando o papel dos cátions trocāveis, na retenção do fósforo, propuseram a ocorrēncia de uma ponte de miscela do solo - cátion trocável - fosfato. Porēm, estudos isotōpicos, estudos com potencial de ācido fosfórico e com resinas de troca (WILD, 1953) tem desacreditado a hipótese da ponte de argila - cātion trocável - fosfato.

DE et alii (1963), sugere que a fixação de fósfọ ro pela montmorilonita e a caulinita era afetada por outros cá tions, sendo maior $\mathrm{com} \mathrm{NH}_{4}, \mathrm{H}$, Na, $\mathrm{Ca}$ e $\mathrm{Mg}$ que com $\mathrm{K}$. No caso da presença de aluminio, cälcio e hidrogênio, CALVERT et alij (1960), afirmam que a intensidade de fixação decresce nessa mes ma ordem. Para os autores, a fixação do fósforo por argila pre viamente acidificada aumenta com a saturação de cálcio, devido à formação de fosfatọ de cálcio complexo.

LARSEN et alij. (1963), mostraram que a reação ini cial de $\mathrm{Ca}\left(\mathrm{H}_{2} \mathrm{PO}_{4}\right)_{2} \cdot 2 \mathrm{H}_{2} \mathrm{O}$ com CaCO 3 levando a formação de $\mathrm{CaHPO}_{4}$ se completava dentro de um tempo de três a quatro dias. SEN GUP TA e CORNFIELD (1963), observaram que em solos com um teor de $\mathrm{CaCO}_{3}$ de 0,15 - 47,2 \%, a quantidade fixada de fósforo aplicado estava melhor correlacionada com o conteúdo de argilas dos so los do que com a porcentagem de $\mathrm{CaCO}_{3}$. 
BOHN e PEECH (1969), referem-se às constantes de equilibrio dos complexos P-Ca e P-Mg para assegurar que tais formas predominam no solo quando o pH ultrapassa o valor de 7,2 .

Estudando a fixação de fósforo em solos tropicais, DABIN (1970), encontrou que para solos ácidos a fração ligada ao cālcio, ao início é despresível, mas pode se tornar conside rável com o decorrer do tempo.

Dentre os mecanismos propostos para explicar o efeito de cālcio na fixação do fósforo na faixa do pH maior que 6,0 , segundo MELLO et alii. (1972) podem-se mencionar: formação de fosfatos de cálcio pouco solüveis, precipitação sobre a superficie das particulas de $\mathrm{CaCO}_{3}$ e fixação pelas argilas saturadas com cālcio.

STRONG e RACZ (1970), trabalhando quatro solos contendo diferentes teores de cālcio e magnésio, tratados com $\mathrm{K}_{2} \mathrm{H} \mathrm{PO}_{4}$ e $\mathrm{KH}_{2} \mathrm{PO}_{4}$ e incubados por vārios meses, constataram a formação de seis diferentes fosfatos de cālcio e magnésio: fos fato bicálcico bihidratado $\left(\mathrm{CaHPO}_{4}, 2 \mathrm{H}_{2} \mathrm{O}\right)$, fosfato bimagnésico trihidratado $\left(\mathrm{MgHPO}_{4}\right.$. $\left.3 \mathrm{H}_{2} \mathrm{O}\right)$, fosfato octacálcico trinidratado $\left(\mathrm{Ca}_{4} \mathrm{H}\left(\mathrm{PO}_{4}\right)_{3} \cdot 3 \mathrm{H}_{2} \mathrm{O}\right)$, fosfato trimagnésico com vinte e duas moléculas de água $\left(\mathrm{Mg}_{3}\left(\mathrm{PO}_{4}\right)_{2} \cdot 22 \mathrm{H}_{2} \mathrm{O}\right)$, fosfato de cálcio e magnésio $\left(\mathrm{Ca}_{3} \mathrm{Mg}_{3}\left(\mathrm{PO}_{4}\right)_{3}\right)$ e fosfato de cálcio $\left(\mathrm{Ca}_{4} \mathrm{P}_{2} \mathrm{O}_{9}\right)$. 


\subsubsection{Influência do $\mathrm{pH}$}

O efeito do pH na fixação do fósforo pelos solos tem sido muito discutido, sendo que a maioria dos pesquisado res concordam que as fixações săo maiores nas faixas extremas de acidez ou alcalinidade.

HSU e JACKSON (1960), observaram que a fração inorgānica do fósforo no solo estava relacionada com o pH. Ací ma de pH 7, o fósforo se unia principalmente ao cálcio; em pH menor que 7 , as frações ligadas ao ferro e ao aluminio aumenta ram. Compostos de fósforo com Al, Fe e Ca, contudo, podem persistir em valores de pH acima ou abaixo de pH 7.

CATANI e PELLEGRINO (1960) concordam com as afir mações de outros autores, ao considerar que para os solos ácidos, os compostos de ferro e alumínio são os maiores responsāveis pela fixação de fósforo, enquanto que, para os solos alca linos são os compostos de Ca e Mg.

RALTJE (1960) propôs um equilíbrio entre as formas de fósforo dos solos de acordo com o pH (Ca-P, Al-P e Fe-P) o qual em condições ácidas é deslocado no sentido da formação de um composto constituido de fosfato e hidróxido de ferro e aluminio. 
PRATT (1966) considera que a solubilidade do ànion do ácido fosförico depende da presença de cátions como: $\mathrm{Ca}, \mathrm{Fe}, \mathrm{Al}$ e $\mathrm{Mg}$. As reações são dependentes de constantes do produto de solubilidade que pode ser relacionado com o pH do solo e quanto menor estiver a constante do produto de solubilida de do $\mathrm{H}_{2} \mathrm{PO}_{4}^{-}$, mais estável será o composto. Mostra o autor que nos casos de extrema acidez, o produto é controlado principalmente pelos ions aluminio e ferro e nos casos de $\mathrm{pH}$ maior que 5 ,pelo cálcio.

GUTNIK et alii (1967), observaram mudança no fe nōmeno de fixação do fósforo pela variação do pH de solos derivados de cinzas vuicânicas, com teores diferentes de aluminio trocável. A quantidade de fósforo retido se correlaciona com o teor de aluminio e a fixação diminui com o aumento do $\mathrm{pH}$.

CABALA e FASSBENDER (1971), estudando oito solos ácidos da Bahia, encontraram que a calagem diminui o poder de fixação atë um pH 5,8, do qual a partir da $\vec{i}$ houve um a umento.

LEAL e VELLOSO (1973), estudando o fosfato adsorvido em latossolos sob vegetação de cerrado, concluiram que o pH teve grande influēncia sobre a adsorção máxima de fosfato nos latossolos estudados, diminuindo com a elevação do pH. 
Ao se elevar o pH da solução de 4,0 para 7,0 o fosfato adsorvi do variou na ordem de 14 a $20 \%$.

Em um outro trabalho com solos de cerrado em Mato Grosso, VASCONCELLOS (1973), encontrou que a adsorção mäxi ma decresceu com o aumento do pti inicial da suspensão, sendo que num dos solos voltou a aumentar apös pH 7,0.

2.2.5. Influência do tempo de contato entre o ion fosfato e o solo

Pesquisadores como DAVIS (1935), COLEMAN (1944) e KURTZ (1953), constataram que a retenção de fósforo pelos so los e pelas argilas do solo ocorre rapidamente nos estágios iniciais, mas que uma pequena reação de fixação continua por muitas semanas.

E admitido por vārios autores (OLSEN e WATANABE, 1957; CHANG e CHU, 1961; HSU, 1965) que a adsorção de fosfatos pelos solos se processa em duas etapas, as quais correspondem inicialmente a uma reação de troca entre os ions fosfatos e hi drōxido da superfície das partículas e a uma reação lenta e continua que se dá pelo aumento gradual do tamanho dos cristais dos fosfatos precipitados do ferro e aluminio. 
DE DATTA et alii (1963), encontraram em um solo, rea ção muito räpido nos primeiros minutos e continuou räpida a tê 48 horas, após o que se tornou lenta, atingindo uma reação muito ien ta após 96 horas.

CATANI e GLORIA (1964) estudando oito solos do Estado de São paulo, em trabaiho com fósforo radioativo ${ }^{32} \mathrm{p}_{15}$, con cluiram que o equilíbrio entre o fósforo fixado e o em solução foi de 16 horas.

RAJAN e FOX (1972), em pesquisas com solos da India e do Hawaii, verificaram que a adsorção de fosfato se dava em duas fases, uma inicial rápida, seguida de outra mais lenta. Os autores consideram que para correlacionar adsorção de fósforo com superfície específica ensaios de curta duração são suficientes. Para se estabelecerem parāmetros relacionados com a nutrição das plantas, o estudo deve ser conduzido em condições de quase equiTî́brio que se obtém após um tempo mínimo de seis dias.

KUO e LOTSE (1972), determinaram a adsorção de fos fato por caulinita saturada com cálcio, e por carbonato de cálcio. Os autores encontraram que $80 \%$ da adsorção de fosfato por carbonato se completa em 10 segundos. Sugerem que o ànion substi tui moléculas de àgua e ou ānions ligados por coordenação com a superficie das particulas. 
Na determinação da capacidade de fixação por so los dos Estados da Bahia e Sergipe, REZENDE (1974), conciui que mais de $80 \%$ do total do fösforo fixado aos dez dias de reação ocorre nas primeiras 24 horas e que a fixação do fósfo ro praticamente estabilizou apōs o quinto dia da reação solofosfato.

BITTENCOURT e ZAMBELLO Jr. (1973), estudando o comportamento do fósforo em solos tropicais através de reações de retenção, observaram que o processo de retenção corresponde a uma etapa inicial mais rápida seguidas de outras que se processam durante um intervalo de tempo maior. Determi naram os autores que a combinação do fósforo com os constituin tes contendo ferro se dá inicialmente de uma maneira mais intensa e apōs atingir um valor máximo tende a decrescer. Por outro lado, a ligaçäo com o aluminio é crescente e constante. 


\section{MATERIAIS E METODOS}

3.1. Solos.

Foram utilizadas amostras do horizonte superfi cial $(A p)$ de dois solos classificados ao nivel de série do Municipio de Piracicaba, São Paulo.

Os solos empregados foram coletados, a uma profundidade não maior de $20 \mathrm{~cm}$, evitando-se obter amostras de àreas adubadas ou submetidas a outras práticas culturais.

$$
\text { As amostras foram secadas ao ar e passadas }
$$

através de peneiras de $2 \mathrm{~mm}$ de malha.

A classificação dos solos conforme RANZANI et alij (1966), assim como a sua localização são apresentadas na Tabela 1 . 
Tabela 1 - Localização e classificação dos solos a nỉver de Série e de Grande Grupo.

\begin{tabular}{|c|c|c|c|c|}
\hline \multirow{2}{*}{$\begin{array}{l}\text { MOQ da } \\
\text { amostra }\end{array}$} & \multirow{2}{*}{ Localidade } & \multirow{2}{*}{ sērie } & \multicolumn{2}{|c|}{ Grande Grupo } \\
\hline & & & $\begin{array}{l}\text { Comissão de } \\
\text { Solos }\end{array}$ & $\begin{array}{l}\text { Soil Survey } \\
\text { Staff }\end{array}$ \\
\hline 01 & $\begin{array}{l}\text { Bairro Paredão } \\
\text { Vermel ho }\end{array}$ & $\begin{array}{l}\text { Paredão Ver- } \\
\text { melho }\end{array}$ & $\begin{array}{l}\text { Latossol Vermelho } \\
\text { Amarelo fase are- } \\
\text { nosa }\end{array}$ & Haplortox \\
\hline 18 & Bairro Tupi & Quebra Dente & $\begin{array}{l}\text { Podzölico Vermelho } \\
\text { Amarelo variação } \\
\text { Laras. }\end{array}$ & Typustaif \\
\hline
\end{tabular}

Utilizou-se dois minērios, um deles contendo altos teores de argila de grade 2:1 com predominância de vermiculita, obtido no Municipio de Catalão, Estado de Goiās, e outro conten do argilas de grade 1:l com dominäncia de caulinita, do Municí pio de Piracicaba, Estado de são Paulo. Os minérios das jazi das foram finamente moidos em um moinho de bola e passados atra vës de peneiras 270 (Tyler) com 0,053 mm de abertura de malha.

Tanto o solo Paredão Vermel ho como o solo Quebra Dente, receberam quantidades variāveis de minério vermiculitico ou caulinitico, obtendo-se amostras homogeneizadas para cada do sagem de solo e minério. Os teores dos componentes das misturas são mostrados na Tabela 2 . 
Tabela 2 - Quantidades de solo e minērio vermiculítico e ou cau linitico nas amostras.

\begin{tabular}{|c|c|}
\hline $\begin{array}{r}\text { No da } \\
\text { amostra }\end{array}$ & Solo e minério de jazida \\
\hline 01 & $100 \%$ Paredão Vermelno \\
\hline 02 & $98,75 \%$ Paredão Vermel ho $+1,25 \%$ Min.Vermiculitico \\
\hline 03 & $97,50 \%$ Paredão Vermelho $+2,50 \%$ Min. Vermiculitico \\
\hline 04 & $95,00 \%$ Paredão Vermel ho $+5,00 \%$ Min.Vermiculitico \\
\hline 05 & $90,00 \%$ Paredão Vermelho $+10,00 \%$ Min. Vermiculitico \\
\hline 06 & $85,00 \%$ Paredão Vermel ho $+15,00 \%$ Min.Vermiculitico \\
\hline 07 & $80,00 \%$ Paredão Vermel ho $+20,00 \%$ Min.Vermiculitico \\
\hline 08 & $75,00 \%$ Paredão Vermel ho $+25,00 \%$ Min.Vermiculitico \\
\hline 09 & $100 \%$ Minério Vermiculitico \\
\hline 10 & $98,75 \%$ Paredão Vermel ho $+1,25 \%$ Min.Caulinitico \\
\hline 11 & $97,50 \%$ Paredão Vermel ho $+2,50 \%$ Min.Caulinitico \\
\hline 12 & $95,00 \%$ Paredão Vermel ho $+5,00 \%$ Min.Caulinittico \\
\hline 13 & $90,00 \%$ Paredão Vermel ho $+10,00 \%$ Min.Caulinittico \\
\hline 14 & $85,00 \%$ Paredão Vermelho $+15,00 \%$ Min.Caulinitico \\
\hline 15 & $80,00 \%$ Paredão Vermel ho $+20,00 \%$ Min.Caulinitico \\
\hline 16 & $75,00 \%$ Paredão Vermel ho $+25,00 \%$ Min.Caulinitico \\
\hline 17 & $100 \%$ Min. Caulinitico \\
\hline 18 & $100 \%$ Quebra Dente \\
\hline 19 & $98,75 \%$ Quebra Dente $+1,25 \%$ Min.Vermiculitico \\
\hline
\end{tabular}


Tabela 2 - Continuação

\begin{tabular}{ccc}
$\begin{array}{c}\text { No da } \\
\text { amostra }\end{array}$ & Solo e minério de jazida (\%) \\
\hline 20 & $97,50 \%$ Quebra Dente $+2,50 \%$ Min.Vermiculitico \\
21 & $95,00 \%$ Quebra Dente $+5,00 \%$ Min.Vermiculitico \\
22 & $90,00 \%$ Quebra Dente $+10,00 \%$ Min.Vermiculitico \\
23 & $85,00 \%$ Quebra Dente $+15,00 \%$ Min.Vermiculitico \\
24 & $80,00 \%$ Quebra Dente $+20,00 \%$ Min.Vermiculitico \\
25 & $75,00 \%$ Quebra Dente $+25,00 \%$ Min.Vermiculitico \\
26 & $98,75 \%$ Quebra Dente $+1,25 \%$ Min.Caulinitico \\
27 & $97,20 \%$ Quebra Dente $+2,50 \%$ Min.Caulinitico \\
28 & $95,00 \%$ Quebra Dente $+5,00 \%$ Min.Caulinitico \\
29 & $90,00 \%$ Quebra Dente $+10,00 \%$ Min.Caulinitico \\
30 & $85,00 \%$ Quebra Dente $+15,00 \%$ Mir.Caulinitico \\
31 & $80,00 \%$ Quebra Dente $+20,00 \%$ Min.Caulinitico \\
32 & $75,00 \%$ Quebra Dente $+25,00 \%$ Min.Caulinitico
\end{tabular}


3.2. Determinação das características físicas e químicas dos solos

As amostras de terra apōs receberem quantidades variāveis de minërio foram analisadas nos laboratōrios do De partamento de Solos, Geologia e Fertilizantes da Escola Supe rior de Agricultura "Luiz de Queiroz" e revelaram as caracte. risticas fisicas e quimicas apresentadas nas tabelas 3 e 4 , res pectivamente.

Tabela 3 - Análise granulométrica das amostras.

\begin{tabular}{lcccccccc}
\hline $\begin{array}{l}\text { No da } \\
\text { a mos- } \\
\text { tra }\end{array}$ & $\begin{array}{c}\text { Argiia } \\
(\%)\end{array}$ & $\begin{array}{c}\text { Areia } \\
\text { total } \\
(\%)\end{array}$ & $\begin{array}{c}\text { Areia } \\
\text { muito } \\
\text { grossa } \\
(\%)\end{array}$ & $\begin{array}{c}\text { Areia } \\
\text { grossa } \\
(\%)\end{array}$ & $\begin{array}{c}\text { Areia } \\
\text { média } \\
(\%)\end{array}$ & $\begin{array}{c}\text { Areia } \\
\text { fina } \\
(\%)\end{array}$ & $\begin{array}{c}\text { Areia } \\
\text { muito } \\
\text { fina } \\
(\%)\end{array}$ & $\begin{array}{c}\text { Limo } \\
(\%)\end{array}$ \\
\hline 01 & 5,1 & 93,2 & 0,2 & 0,5 & 9,3 & 72,6 & 10,6 & 1,7 \\
02 & 7,5 & 89,0 & 0,5 & 0,6 & 9,9 & 67,8 & 10,2 & 3,5 \\
03 & 8,3 & 88,0 & 0,2 & 0,7 & 10,7 & 67,5 & 8,9 & 3,7 \\
04 & 8,9 & 85,1 & 0,2 & 0,9 & 10,6 & 63,5 & 9,9 & 6,0 \\
05 & 10,6 & 79,3 & 0,1 & 0,7 & 9,6 & 59,4 & 9,5 & 10,1 \\
06 & 10,8 & 75,2 & 0,3 & 0,7 & 9,5 & 55,6 & 9,1 & 14,0 \\
07 & 12,0 & 69,1 & 0,7 & 0,6 & 9,4 & 52,9 & 6,1 & 18,9 \\
08 & 12,6 & 67,9 & 0,1 & 0,6 & 8,6 & 50,3 & 8,3 & 19,5 \\
09 & 15,8 & 9,0 & 0,0 & 0,0 & 0,2 & 0,1 & 8,7 & 75,2 \\
10 & 7,7 & 88,5 & 0,4 & 0,7 & 9,9 & 68,4 & 9,1 & 3,8 \\
(Continua) & & & & & & &
\end{tabular}


Tabela 3 - Continuação

\begin{tabular}{|c|c|c|c|c|c|c|c|c|}
\hline $\begin{array}{l}\text { No da } \\
\text { amos- } \\
\text { tra }\end{array}$ & $\begin{array}{c}\text { Argila } \\
(\%)\end{array}$ & $\begin{array}{c}\text { Areia } \\
\text { total } \\
(\%)\end{array}$ & $\begin{array}{c}\text { Areia } \\
\text { muito } \\
\text { grossa } \\
(\%)\end{array}$ & $\begin{array}{c}\text { Areia } \\
\text { grossa } \\
\qquad \%)\end{array}$ & $\begin{array}{c}\text { Areia } \\
\text { média } \\
(\%)\end{array}$ & $\begin{array}{l}\text { Areia } \\
\text { fina } \\
(\%)\end{array}$ & $\begin{array}{l}\text { Areia } \\
\text { muito } \\
\text { fina } \\
(\%)\end{array}$ & $\begin{array}{l}\text { Limo } \\
(\%)\end{array}$ \\
\hline 11 & 9,5 & 84,7 & 0,2 & 0,6 & 10,2 & 65,9 & 7,8 & 5,8 \\
\hline 12 & 11,3 & 84,4 & 0,0 & 0,2 & 9,3 & 65,0 & 9,9 & 4,3 \\
\hline 13 & 12,8 & 78,6 & 0,0 & 0,3 & 8,7 & 61,0 & 8,6 & 8,6 \\
\hline 14 & 16,9 & 73,9 & 0,0 & $\cdot 0,1$ & 6,8 & 57,7 & 9,3 & 9,2 \\
\hline 15 & 19,9 & 69,9 & 0,0 & 0,2 & 6,5 & 54,7 & 8,5 & 10,2 \\
\hline 16 & 22,6 & 68,2 & 0,0 & 0,2 & 6,4 & 52,6 & 9,0 & 9,2 \\
\hline 17 & 67,9 & 2,7 & 0,0 & 0,0 & 2,0 & 0,7 & 8,7 & 29,6 \\
\hline 18 & 7,3 & 73,0 & 0,0 & 0,7 & 16,8 & 41,5 & 14,0 & 19,7 \\
\hline 15 & 7,8 & 71,9 & 0,0 & 1,2 & 14,0 & 43,0 & 13,7 & 20,3 \\
\hline 20 & 8,3 & 71,7 & 0,0 & 1,2 & 13,5 & 42,7 & 14,3 & 20,0 \\
\hline 27 & 8,1 & 68,8 & 0,1 & 1,3 & 13,3 & 41,1 & 13,0 & 23,1 \\
\hline 22 & 9,1 & 66,1 & 0,0 & 1,3 & 13,7 & 35,1 & 12,0 & 24,8 \\
\hline 23 & 10,4 & 64,6 & 0,0 & 1,2 & 12,7 & 36,2 & 14,5 & 25,0 \\
\hline 24 & 10,7 & 58,9 & 0,0 & 1,2 & 12,5 & 34,8 & 10,4 & 30,4 \\
\hline 25 & 12,2 & 52,6 & 0,1 & 1,0 & 10,9 & 32,1 & 8,5 & $3,5,2$ \\
\hline 26 & 7,9 & 72,7 & 0,1 & 1,4 & 14,7 & 42,4 & 14,1 & 19,4 \\
\hline 27 & 9,2 & 70,9 & 0,1 & 1,5 & 14,3 & 42,8 & 12,2 & 19,9 \\
\hline 28 & 11,1 & 67,6 & 0,0 & 1,3 & 14,0 & 40,8 & 11,5 & 21,3 \\
\hline 29 & 13,4 & 64,7 & 0,0 & 1,3 & 13,2 & 39,4 & 10,8 & 22,5 \\
\hline 30 & 16,7 & 63,1 & 0,2 & 1,4 & 12,8 & 37,7 & 11,0 & 20,2 \\
\hline 31 & 17,9 & 58,7 & 0,0 & $. .1,1$ & 12,1 & 35,0 & 10,5 & 23,4 \\
\hline 32 & 21,7 & 55,5 & 0,1 & 1,1 & 11,6 & 33,0 & 9,7 & 22,8 \\
\hline
\end{tabular}




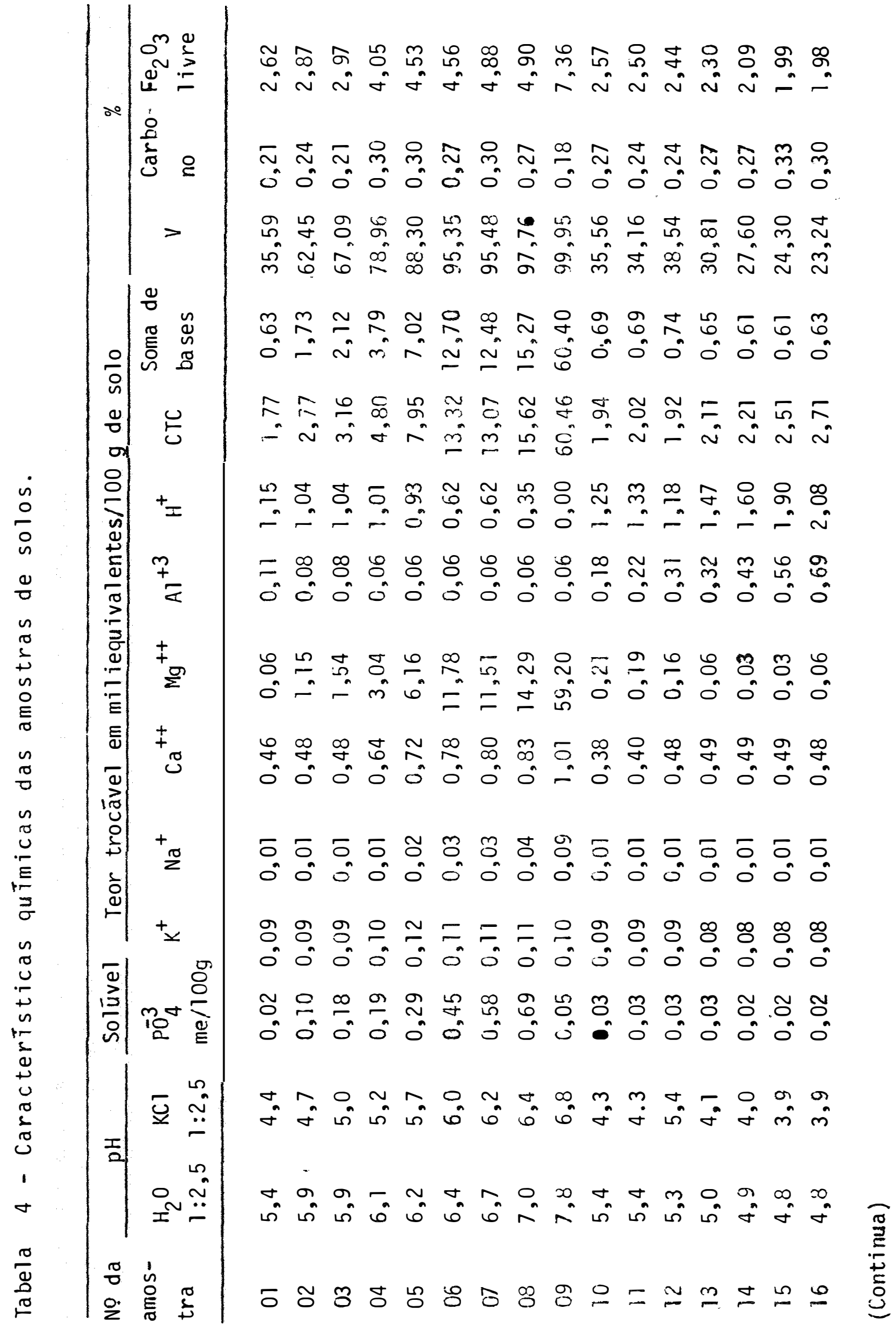




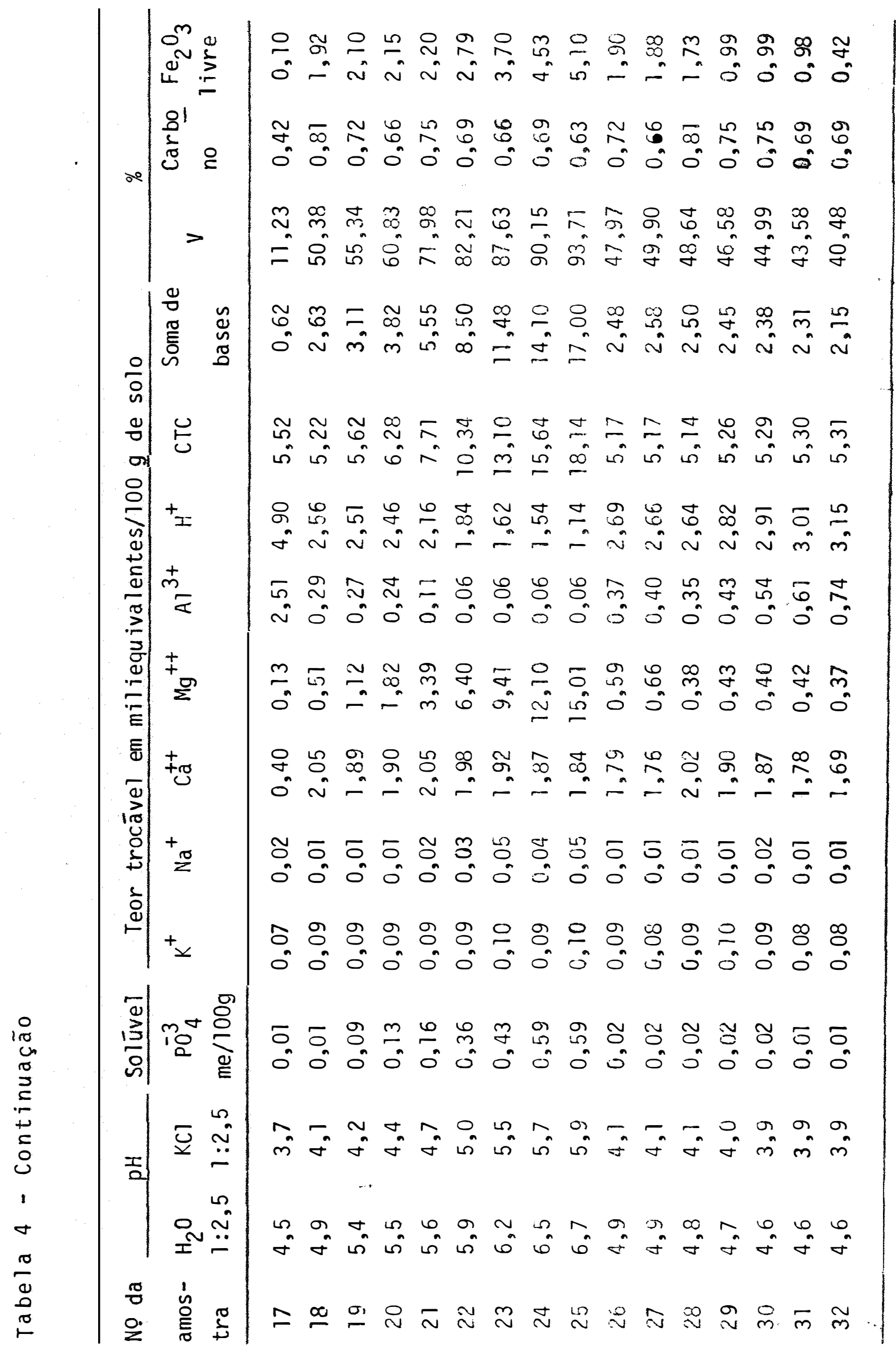


Determinou-se o teor de fósforo total dos solos Paredão Vermelho e Quebra Dente, e dos minérios de jazida ver miculitico e caulinitico. Os valores obtidos estáo contidos na Tabela 5 .

Tabela 5 - Teor de fósforo total.

\begin{tabular}{|c|c|c|}
\hline No da amostra & Amostra & $\begin{array}{l}\text { Fósforo }{ }_{3} \text { Total } \\
\left.\text { (me } \mathrm{PO}_{4}^{3} / 100 \mathrm{~g}\right)\end{array}$ \\
\hline 01 & Solo Paredão Vermelho & 0,15 \\
\hline 09 & Minērio Vermiculitico & 1,86 \\
\hline 17 & Minërio Caulinitico & 0,08 \\
\hline 18 & Solo Quebra Dente & 0,18 \\
\hline
\end{tabular}

3.2.1. Métodos analiticos utilizados nas determinações das caracteristicas físicas e quimicas das amos tras

3.2.1.1. Anālise granulométrica

Na determinação das classes de separados do solo foi utilizado o método da pipeta (KILMER e ALEXANDER, 1949), em pregando-se como dispersante uma solução de hexametafosfato de sódio a $5 \%$. 
As determinações para $\mathrm{pH}, \mathrm{C}, \mathrm{PO}$
$\equiv$ (1974).

3.2.1.3. Determinação dos óxidos de ferro livre

As percentagens dos óxidos de ferro livre no so10 foram obtidas pelo método preconizado por MEHRA e JACKSON (1960), utilizando-se citrato de sódio como complexante, bicar bonato de sódio como tampão e ditionito de sódio como agente redutor. A cor foi desenvolvida com tiocianato de potássio e a leitura feita em um colorimetro fotoelétrico usando filtro no 54 a um comprimento de onda de $490 \mathrm{mu}$.

3.2.1.4. Determinação do fósforo total

0 fósforo total das amostras foi avaliado empregando-se uma solução extratora de ácido perclórico a $60 \%$, após se destruir a matēria orgānica com $\mathrm{HNO}_{3}$ e $\mathrm{HCl}$. As leituras foram feitas em um colorímetro uma vez desenvolvida a cor do àci do molibdovanadofosfórico, segundo o método de KITSOH e HELLONS (1944). 


\subsection{Anālise mineralógica da fração argila.}

Na determinação mineralógica das argilas silicatadas das amostras de solo e dos minérios das jazidas, procedeu-se conforme os métodos descritos por JACKSON (1956).

Utilizou-se $30 \mathrm{~g}$ de TFSA da amostra, as quais foram submetidas a diferentes tratamentos atē a obtenção das argilas cristalinas, em condição de serem analisadas por difra tometria de raios $-x$.

Os tratamentos constaram da remoção dos sais soTúveis e cātions bivalentes trocāveis com uma solução tampão de acetato de sōdio I N pH 5. A matéria orgânica e os óxidos de manganês livres foram removidos com peróxido de hidrogēnio a $30 \%$ e para a remoção dos óxidos de ferro livres empregouse ditionito, citrato e bicarbonato de sódio que agem como redutor, quelante e tampão, respectivamente.

Para a dispersão e fracionamento das amostras, se parou-se as partîculas maiores de 50 u (fraçăo areia total) com um tamis de 0,05 mm de malha, utilizando como dispersante uma solução de carbonato de sōdio pH 9,5. Deixou-se sedimentar - silte de acordo com a Lei de Stokes (TEIXEIRA MENDES, 1972), para depois sifonar a fração argila. 
A fração argila obtida da amostra, foi saturada com potāssio ou com magnésio para a anālise qualitativa. Proce deu-se a sucessivas lavagens com àgua, etanol e acetona a té a eliminação total do cloreto. Posteriormente uma certa porção de argila saturada transferiu-se para läminas de vidro. No caso das amostras saturadas com potássio, foram aquecidas a $350^{\circ} \mathrm{C}$ e $550^{\circ} \mathrm{C}$ durante duas horas. As amostras saturadas com magnésio foram glicoladas (glicerol a 10 \% em solução alcoólica).

As lãminas saturadas com potássio a temperatura ambiente e as aquecidas $\left(350^{\circ}\right.$ e $\left.550^{\circ} \mathrm{C}\right)$, bem como as saturadas com magnésio (glicoladas), foram irradiadas no aparelho de raio$x$ com tubo de cobal to no intervalo de $2^{\circ}-32^{\circ} 2 \theta$.

\subsubsection{Reconhecimento dos minerais de argila}

Uma vez obtidos no aparelho de raio-X os difrato gramas das amostras, a temperaturas ambiente, aquecidas e gli coladas, foi feita a identificação dos minerais componentes da fração argila mediante a determinação dos espaços.interplana res (distãncia basal). Na Tabela 6 ilustram-se os valores obti dos para alguns minerais de argila submetidos a diversos trata mentos de acordo às especificações de Lucas et alij (NEvES, 1968). 
Tabela 6 - Alguns minerais de argila e seus espaçamentos basais respectivos.

\begin{tabular}{|c|c|c|c|c|c|}
\hline \multirow{4}{*}{ Minera is } & \multicolumn{5}{|c|}{ Espaçamentos basais } \\
\hline & \multicolumn{3}{|c|}{ Saturação com $K$} & \multirow{3}{*}{$\begin{array}{l}\text { Sa turação } \\
\text { com Mg } \\
\text { gl icolada }\end{array}$} & \multirow{3}{*}{$\begin{array}{l}\text { Outros e } \underline{\text { s }} \\
\text { paçamentos } \\
\text { Sat. com K }\end{array}$} \\
\hline & \multirow{2}{*}{$\begin{array}{l}\text { Natural } \\
\left(25^{\circ} \mathrm{C}\right)\end{array}$} & \multicolumn{2}{|c|}{ Aquecido } & & \\
\hline & & $350^{\circ} \mathrm{C}$ & $550^{\circ} \mathrm{C}$ & & \\
\hline Caulinita & $7,2 \AA$ & $7,2 \AA$ & - & $7,2 \AA$ & $3,5 \AA$ \\
\hline Il ita & $10 \%$ & $10 \AA$ & $10 \AA$ & $10 \AA$ & $5,0-3,3 \AA$ \\
\hline $\begin{array}{l}\text { Montmori- } \\
\text { lonita }\end{array}$ & $12-14 \AA$ & $10 \%$ & $10 \AA$ & $17 \AA$ & $5,1-3,05 \AA$ \\
\hline Vermiculita & $12-14 \AA$ & $10 \&$ & $10 \AA$ & $14 \AA$ & $5,0-3,2 \AA$ \\
\hline
\end{tabular}

Nas Figuras $1,2,3$ e 4 apresentam-se os difratogramas das amostras de argila dos solos após ter sido submeti das aos diversos tratamentos e irradiações com raio-X. 


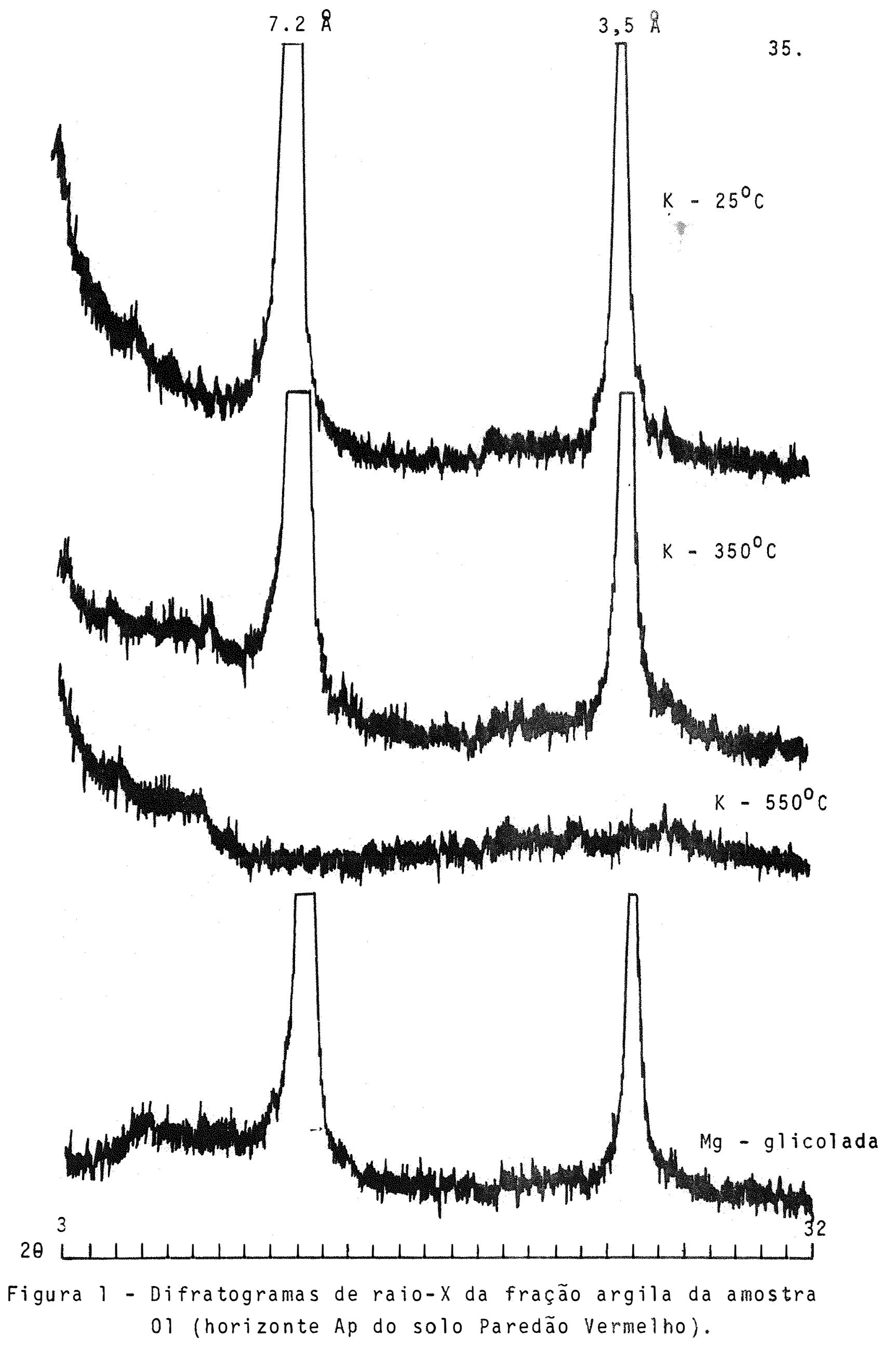




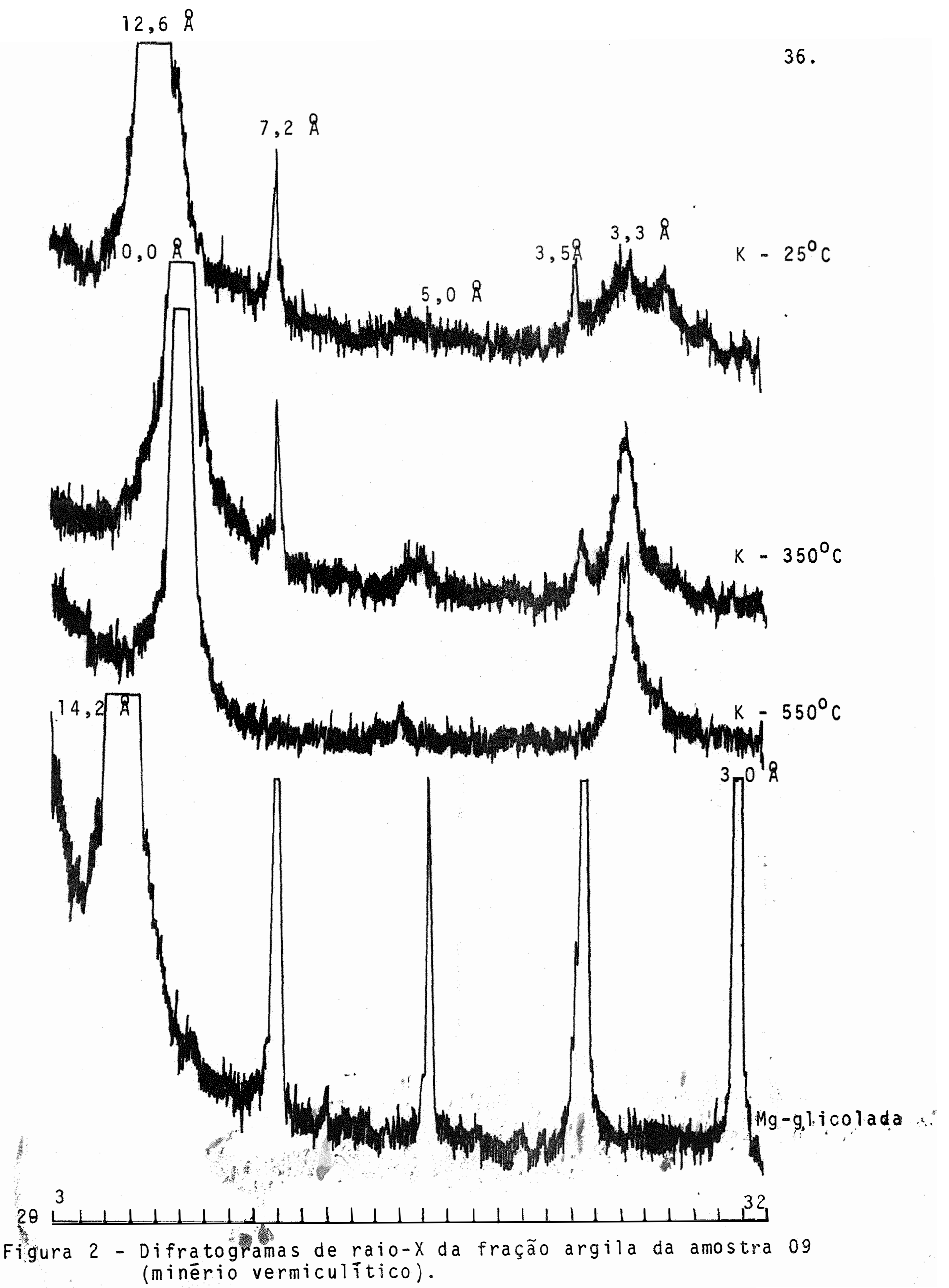




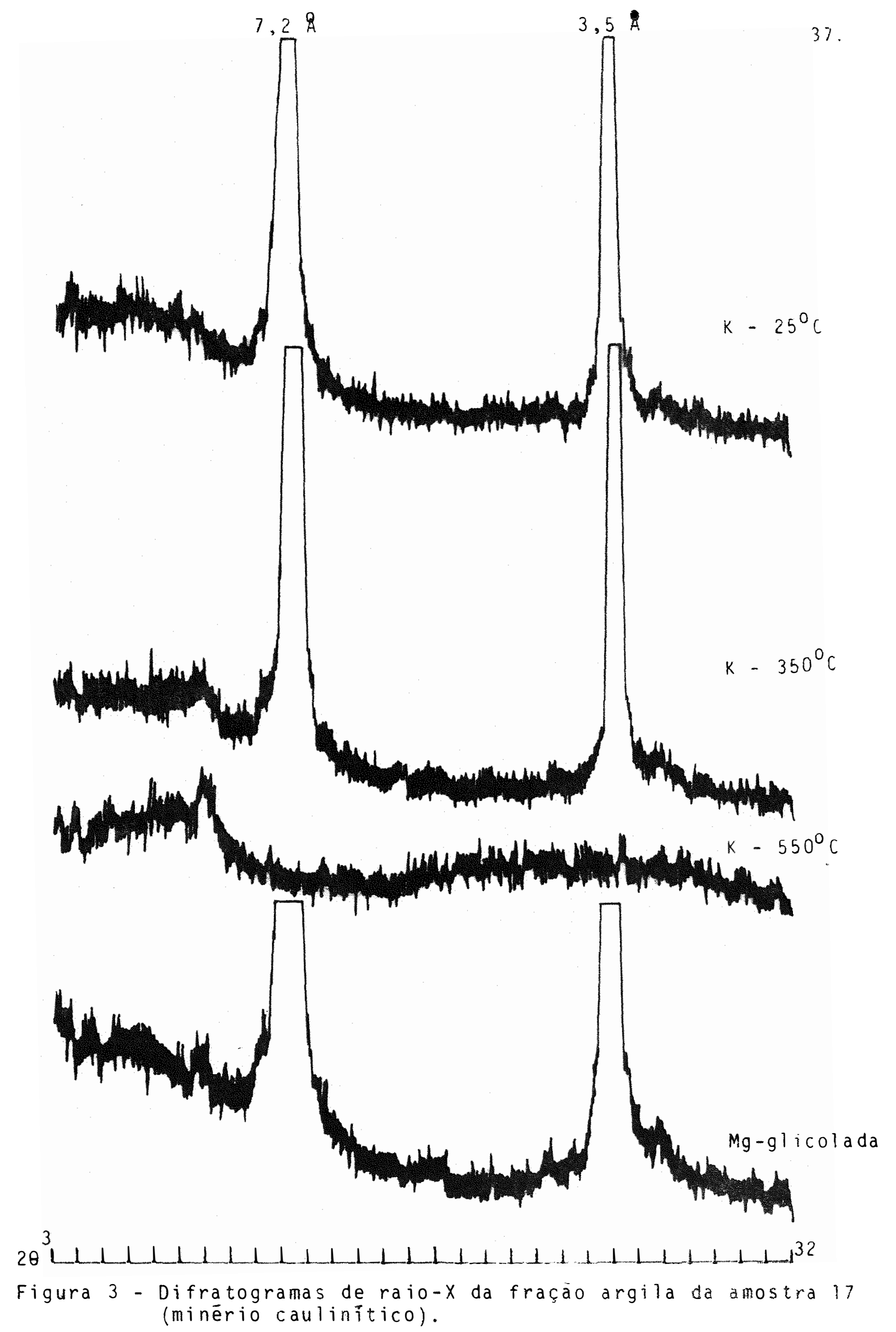




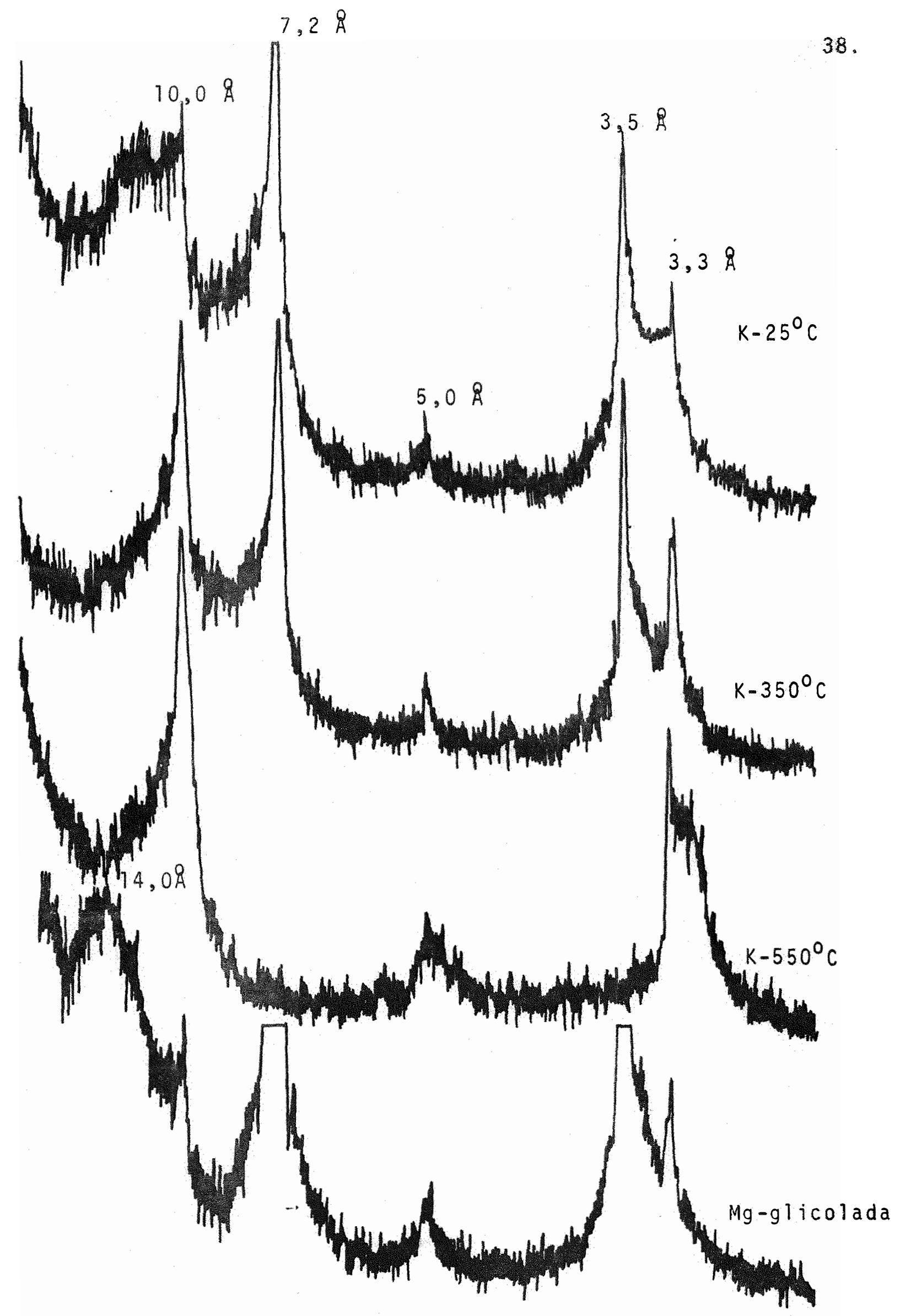

3 32

281

Figura 4 - Difratogramas de raio-X da fração argila da amostra 18 (horizonte Ap do solo Quebra Dente). 
os resultados obtidos da mineralogia da fração argila das amostras, baseados na identificação dos respectivos difratogramas são dados na Tabela 7.

Tabela 7 - Anālise mineralōgica da fração argila das amóstras.

\begin{tabular}{|c|c|c|c|c|}
\hline \multirow{2}{*}{$\begin{array}{l}\text { Nọ da } \\
\text { amostra }\end{array}$} & \multirow{2}{*}{ Amostra } & \multicolumn{2}{|c|}{ Minerais de argila } & contidos $(x)$ \\
\hline & & Caulinita & Vermiculita & Ilita \\
\hline 01 & $\begin{array}{l}\text { Solo Paredão ver- } \\
\text { melho }\end{array}$ & $x$ & & \\
\hline 09 & Min. Vermiculitico & $x$ & $x$ & $x$ \\
\hline 17 & Min.Caulinitico & $x$ & & \\
\hline 18 & Solo Quebra Dente & $x$ & $x$ & $x$ \\
\hline
\end{tabular}

3.4. Determinação da capacidade de fixação de fösforo pelas amostras

Foram transferidas 10 g de cada amostra de terra para frascos de Erlenmeyer de $150 \mathrm{ml}$ de capacidade e adicionouse $4 \mathrm{ml}$ de uma solução 125 e 250 ppm de fósforo na forma de fosfato monocālcico, resultando nas concentrações finais de 50 e 100 ppm de $P$ no solo. Foi prestada atenção especial à distrị buição homogēnea das soluções às terras, procurando umedecê- 
las por igual. Para cada tratamento foram feitas quatro repetições e estabelecida uma testemunha, a qual somente foi umedecida com āgua destilada.

Depois de tampadas com papel de filtro, cobertos com papel de aluminio para evitar evaporação e incubadas por periodos de 10 e 20 dias, foram adicionadas às amostras $100 \mathrm{ml}$ de solução extratora $\left(\mathrm{H}_{2} \mathrm{SO}_{4} 0,05 \mathrm{~N}\right)$ e agitadas 15 minutos em agitador horizontal circular, conforme o método do IAC (CATANI e JACINTHO, 1974). Pipetaram-se aliquotas para a dosagem dos teores de fósforo pelo método do fosfo-molibdato de amōnio,usan do como redutor o ácido ascórbico. Como as concentrações em fós foro das amostras eram muito diferentes, as aliquotas variaram entre 1 e $5 \mathrm{ml}$ de extrato.

\section{Cálculo da porcentagem de fósforo fixado}

A porcentagem de fixação do fösforo foi calculada mediante a seguinte fórmula:

$$
\% P \text { fixado }=100-\frac{(A-B)}{C} \times 100
$$

sendo:

$$
\begin{aligned}
& A=\text { fósforo em ppm obtido após incubação } \\
& B=\text { fósforo em ppm originārio do solo } \\
& C=\text { fósforo em ppm adicionado ao solo. }
\end{aligned}
$$


4.1. Efeito na fixação de fósforo causado por doses crescentes de minério vermiculittico nas amostras de terra dos solos Paredão Vermelho e Quebra Dente

As médias das quantidades de fösforo fixado pelas amostras com teores variāveis de minério vermiculiticó, ex pressas em ppm e suas respectivas porcentagens, bem como os va lores das diferenças minimas significativas do teste de Tukey, estão contidas nas Tabelas 8 e 9 .

Os resultados apresentados nas Tabelas 8 e 9 , mos tram um acréscimo da capacidade de fixação de fósforo pelas amostras dos dois solos quando o teor do minërio aumentou. Observa-se que a quantidade de fósforo fixada cresceu em valores absolutos (ppm de P) e em valores relativos (\% de. p fixado). 


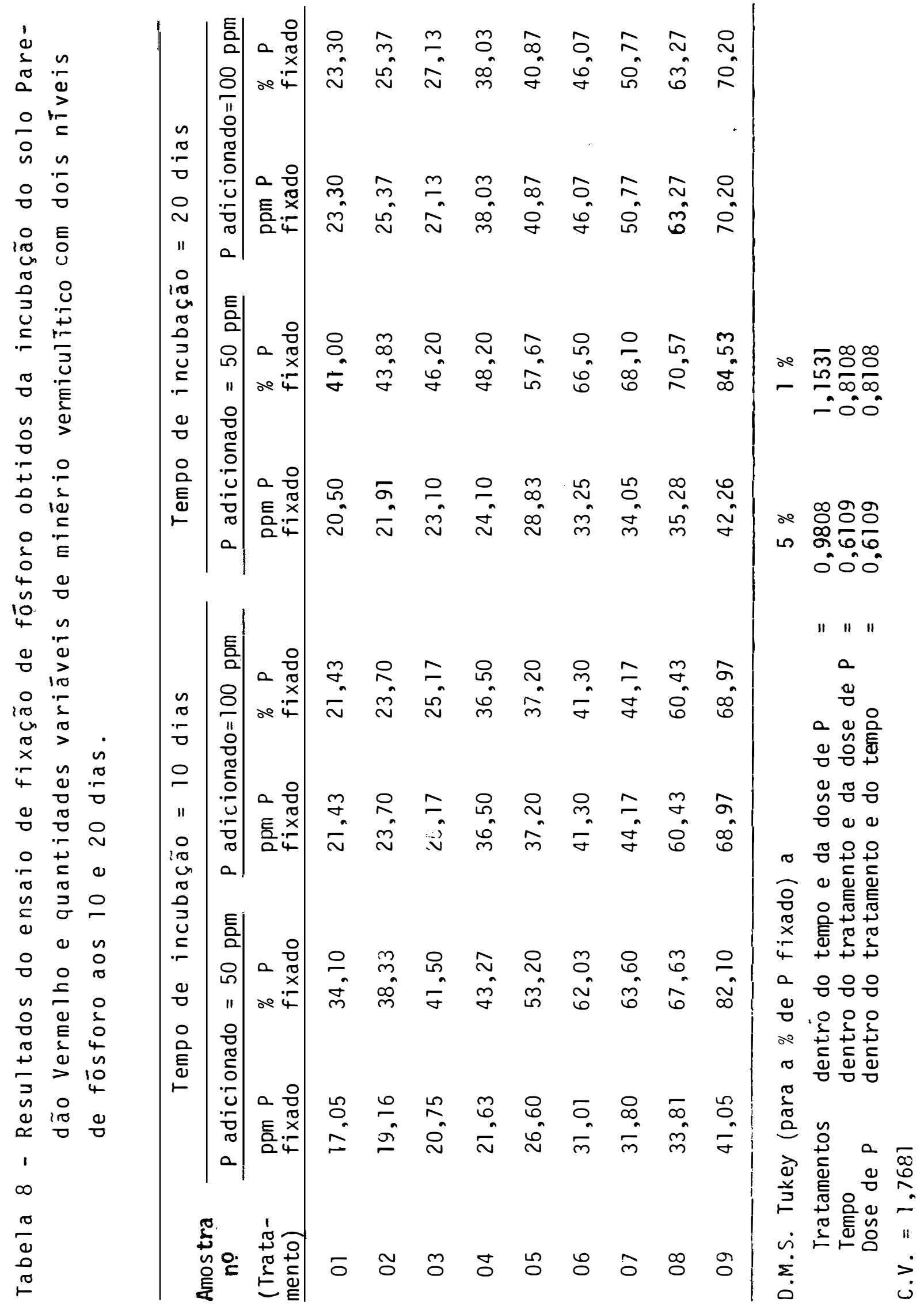


$\stackrel{1}{3} \frac{1}{3}$

$0 \stackrel{n}{0}$

is $r$

은

웅 웅

in

กั

u 0

U.

ช

\& u

을

$\mp \stackrel{0}{7}$

음

인

足.

乞 $E$

4 은

요

-

in

un 1 ro

$x$
$\pi$

4

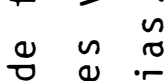

-

$\therefore$.

$\sigma \cdot-\sim$

气

- ํำ

○

$\begin{array}{lll}0 & 0 & n \\ 0 & 0 & 0\end{array}$

Ð

$\pm \stackrel{0}{\square}$

ज)

× 10

,

a

0
0
0
10

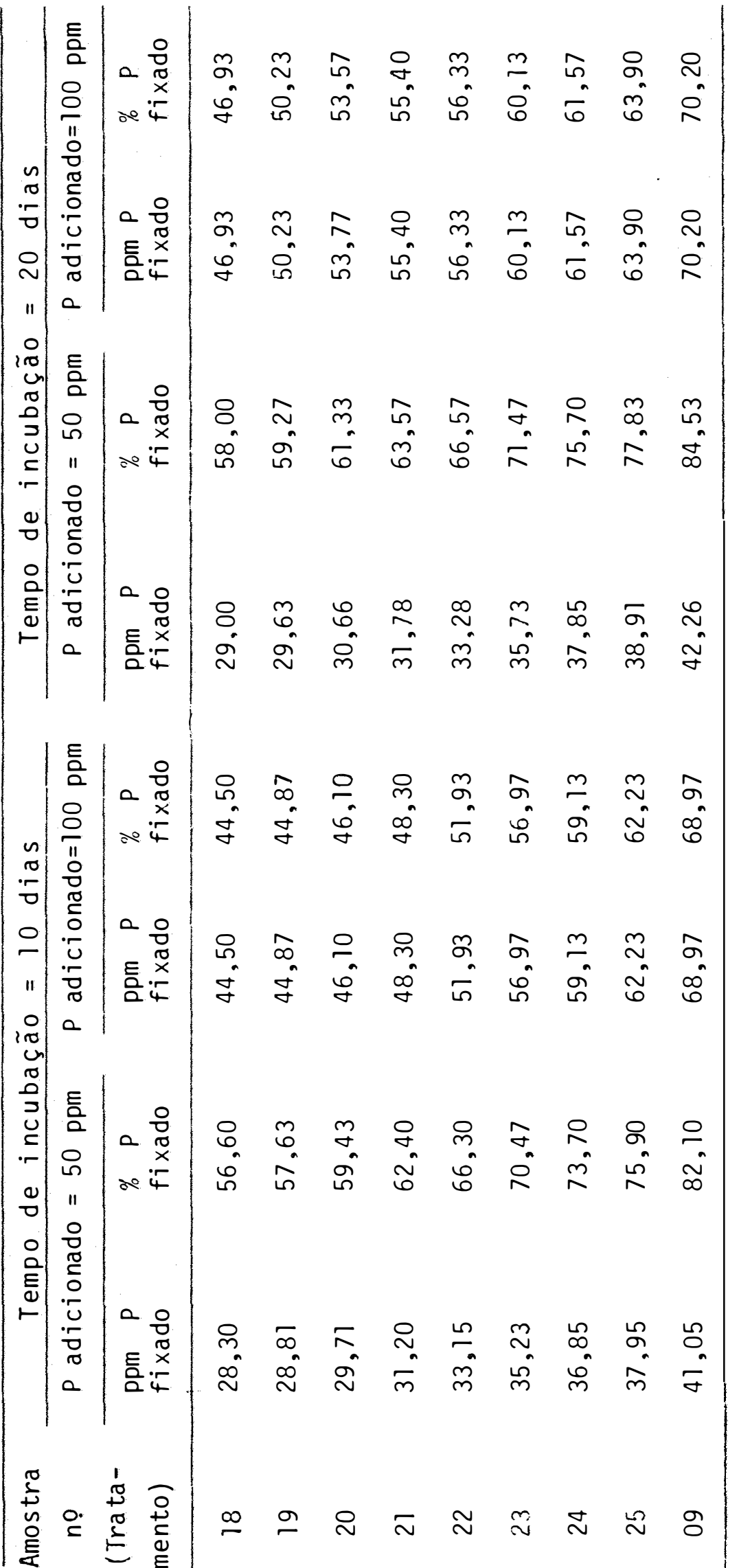

요용요

- 8웅 -00 $\infty$ $\infty$ in กั0

11 $11 \quad 11$

a

임

○ 을 ه 웜

음 중음 음 \& - 중웅어

- $5 \overline{2}$

웅웛듀

전

ㅇ 음응으

잉

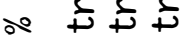

ช बे बे

$\frac{2}{2}$

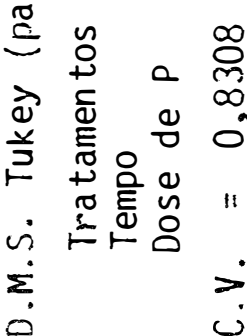


A anāilise de variāncia dos tratamentos, apresen tada na Tabela lo, revelou um efeito significativo da argila adicionada, do tempo de reação e da dose de fosfato sobre a por centagem de fōsforo fixado. Devido ao fato das interações ter sido significativas, efetuou-se o desdobramento das mesmas, in cluindo-se as diferenças minimas significativas fornecidas pe10 teste de Tukey.

Tabela 10 - Anālise de variāncia para a porcentagem de $\mathrm{P}$ fixa do pelas amostras com doses crescentes de minério vermicuititico.

\begin{tabular}{|c|c|c|c|c|c|}
\hline \multirow{2}{*}{$\begin{array}{l}\text { Causas de } \\
\text { Variação }\end{array}$} & \multirow{2}{*}{ G.L. } & Paredão & \multirow{2}{*}{$\frac{\text { Vermelho }}{F}$} & \multicolumn{2}{|c|}{ Quebra Dente } \\
\hline & & Q.M. & & Q.M. & $F$ \\
\hline Tempo ( $T$ ) & 1 & 373,71 & $2661,31 * \star$ & 200,09 & $1860,59 * \star$ \\
\hline Dose de $P(P)$ & 1 & 6007,69 & $42782,23 \star \star$ & 4089,76 & 38029,91 * \\
\hline $\begin{array}{l}\text { Dose de argi- } \\
\text { la (A) }\end{array}$ & 8 & 2982,06 & $21235,94 \star \star$ & 858,73 & $7985,25 * \star$ \\
\hline$T \times P$ & 1 & 18,01 & $128,22 \star \star$ & 38,64 & $359,27 \star \star$ \\
\hline$T \times A$ & 8 & 3,52 & $25,04 \star \star$ & 3,58 & $33,28 * \star$ \\
\hline$P \times A$ & 8 & 59,47 & $423,52 * \star$ & 5,78 & $53,75 \star \star$ \\
\hline$T \times P \times A$ & 8 & 3,90 & $27,80 * \star$ & 4.98 & $46,34 * \star$ \\
\hline Resíduo & 72 & 0,1404 & & 0,1075 & \\
\hline Total & 107 & & & & \\
\hline $\begin{array}{l}\star \quad-\text { signif } \\
\star \star \quad-\text { signif }\end{array}$ & $\begin{array}{l}\text { icat } \\
\text { icat }\end{array}$ & $\begin{array}{llll}0 & \text { a } & 5 & \% \\
0 & \text { a } & 1 & \%\end{array}$ & & & \\
\hline
\end{tabular}


Dos dados das Tabelas 8 e 9, pode-se inferir que a argila vermiculita teve um efeito nivelador nas quantidades de fosfato fixado quando as amostras apresentaram maiores teores de minērio, aproximando-se das porcentagens fixa das pelo minério puro. As amostras que receberam as menores doses mostraram uma fixação maior para o solo Quebra Dente, quando comparadas com o solo Paredão Vermelho. Provavelmente a explicação estā nas diferenças das características físicas, químicas e mineralōgicas.

As ilustrações gräficas dos tratamentos com os solos Paredão Vermelho e Quebra Dente são mostradas pelas Figuras 5 e 6 , onde as porcentagens de fósforo fixado em função do teor de minērio vermiculitico adicionado estão representa das pelas curvas de maior significância, sendo as equações de regressão de terceiro grau com altos valores para $R^{2}$.

As curvas apresentadas (Figuras 5 e 6 ), mostram um comportamento semelhante no mesmo solo quando submetidos aos diferentes tratamentos. Verifica-se que a fixação quase estabilizou nas amostras com as doses maiores de vermiculita. Confrontando as Figuras, observa-se que a inclinação das curvas dos tratamentos de vermiculita com o solo paredão Verme lho, revela um efeito maior da argila adicionada, mostrando uma variação maior đas porcentagens de fösforo fixado entre as doses menores e maiores, quando comparados aos tratamentos da argila com o solo Quebra Dente. 


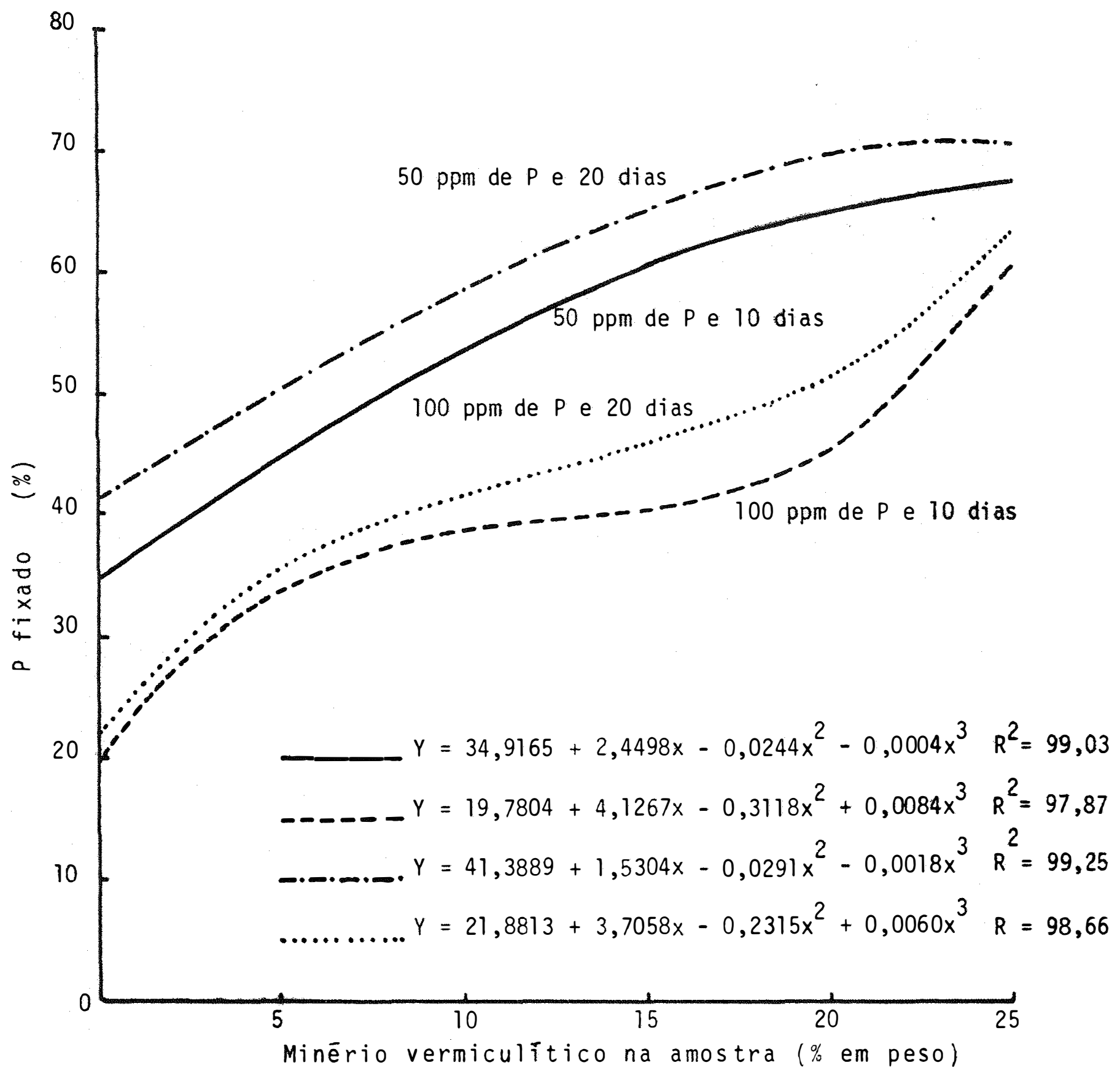

Figura 5 - Curvas de fixação de P para o solo Paredão Vermelho com doses variāveis de minério vermiculitico. 
47.

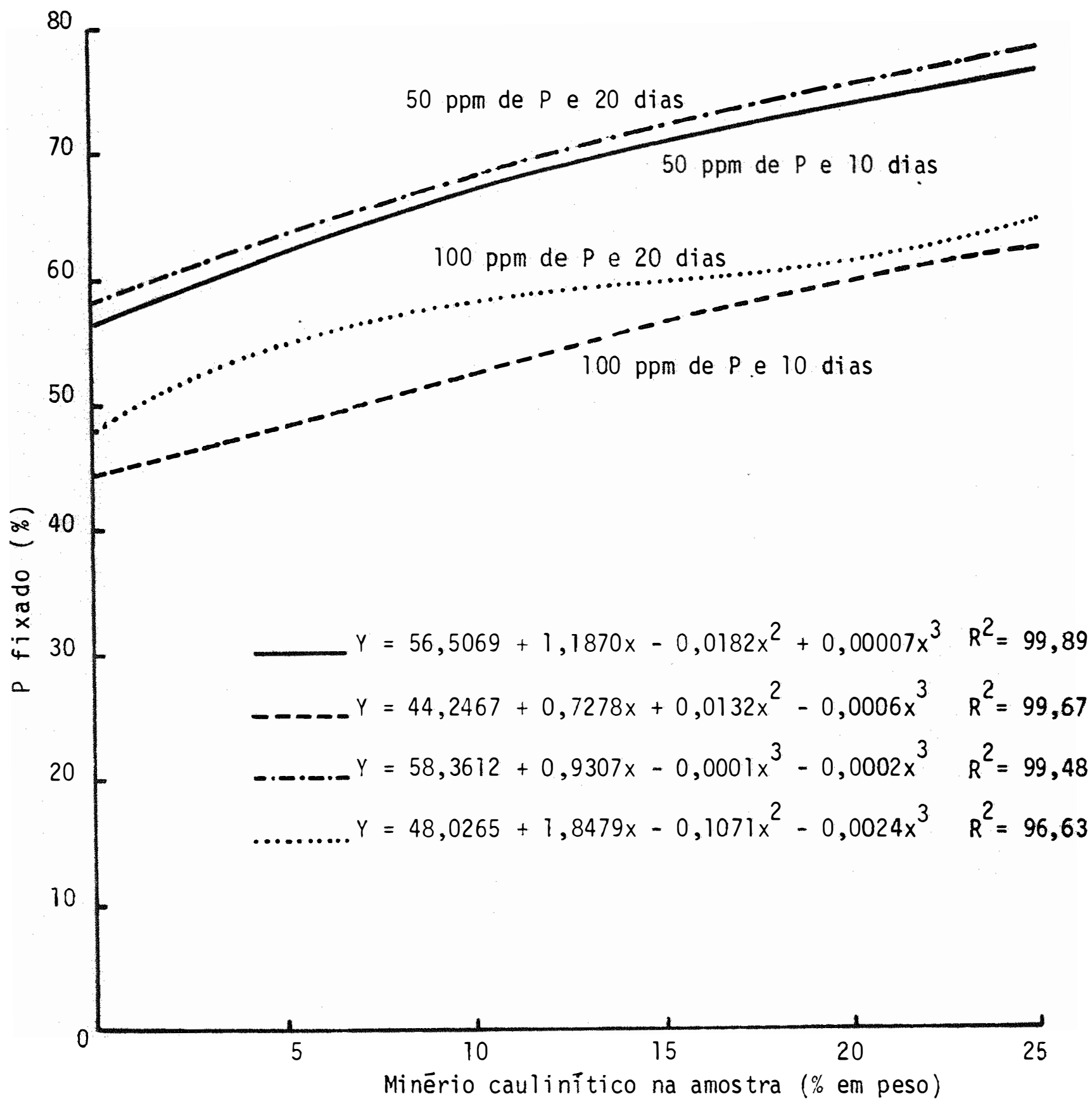

Figura 6 - Curvas de fixaçãa de P para o solo Quebra Dente com doses variāveis de minério vermiculitico. 
Das equaçöes de regressão, obteve-se, para os tra tamentos com o solo Paredão Vermelho na dose de $50 \mathrm{ppm}$ de $P$ e 10 dias de incubação, uma māxima fixação de fósforo de 67,46\% correspondente a $26,85 \%$ de minério vermiculitico na amostra. Para o solo Quebra Dente a máxima porcentagem de fósforo fixado, com o mesmo tratamento, foi de $79,78 \%$, obtida para um teor de $44,85 \%$ do minério na amostra.

Admite-se que a fixação de fósforo está relacionada com vārias caracteristicas dos solos. Consequentemente, pretende-se discutir o fenômeno da fixação tomando como base o teor e a natureza das argilas adicionadas, mas sempre ligando os fatores: $p H$, areia total, ferro livre, aluminio, cáicio, magnésio, capacidade de troca cationnica e percentagem da saturação de base das amostras, que podem ou não,agir simultanea mente.

Pela observação das Tabelas 3 e 4 , que apresen tam as caracteristicas físico-químicas das amostras, nota-se um efeito de diluição ou de concentração nas características do solo original, provocadas como resultado do aumento do teor de argila adicionada. Tendo-se que o efeito de um fator possa ser mascarado e sua influência no ensaio apareça diferente daquela que teria quando isoladamente. Infere-se, que o aumento de pH nas amostras com doses crescentes de vermiculita é conse quência da adição do minério, o qual apresenta um pH alcalino 
$(7,8)$, associado a elevados teores de $M g$, que incide no aumento da capacidade de troca cationica e da porcentagem de satura ção de bases das amostras. O mesmo acontecendo para a porcenta gem de óxido de ferro livre, sendo que a adição induziu diluições nos porcentuais de areia total e de aluminio trocávèl.

\subsubsection{Influência do teor e da natureza da argila}

A influência positiva do teor e da natureza da argila na fixação de fosfato, encontrada neste ensaio para a argila vermiculita, com correlações positivas e altamente significativas, tem sido mostrada por um extenso número de trabaIhos.

HALL e BAKER (1971), ressaltam a importância da natureza das argilas silicatadas na fixação de fosfato. COLE e JACKSON (1950), evidenciam que entre os argilo-minerais, o gru po da vermiculita parece apresentar maior poder de fixação. Correlações positivas tem sido encontradas entre o conteúdo de argila e o fósforo fixado em um grupo de oxissōis e ultissóis do Sul do Brasil (SYERS et alii, 1971) e com nove oxissóis do Brasil Central (LEAL e VELLOSO, 1973).

Entre solos de mineralogia similar, a fixação de fósforo aumenta, com um acréscimo do conteúdo de argila. Não obstante, existem discrepāncias entre os autores para explicar 
o fenômeno da fixação pela argila. COLLEMAN (1944), estudando os mecanismos envolvidos no processo de fixação, aponta que os ions oxidrilas da rede cristalina de argilas silicatadas da caulinita e da montmorilonita pouco contribuem à fixação de fosfato e que esta se deve a troca anionica entre os ions fos fatos e as oxidrilas do capeamento de hidróxidos livres de ferro e aluminio dificilmente removiveis das argilas. Estas afirmações foram enfatizadas por ELLIS e TROUG (1955), ao veri ficarem que a montmorilonita desprovida de capeamento de hidrōxidos de ferro e de aluminio é praticamente incapaz de fixar fósforo. O oposto é afirmado por Milar (1955), citado por CAVALCANTI (1974), que considera que argilo-minerais que possuem $O H$ são capazes de reter ions fosfatos, adianta que tal processo ocorre na superficie desses minerais sem excluir a possibilidade de tais penetrarem entre as unidades básicas.

\subsubsection{Influência do $\mathrm{pH}$}

No que tange à reação do solo, as correlações positivas e altamente significativas encontradas entre o $\mathrm{pH}$ e as porcentagens de fósforo fixado pelas amostras podem ser consideradas com base na dependencia que existe entre pH e a disponibilidade do Fe, Al, Ca e Mg no solo. Bradfield et alif (1935), citado por RODRIGUEZ (1980), propuseram a seguinte ex plicação para os mecanismos envolvidos na fixação de $P$ confor 
me ao pH do solo: a) na faixa de pH entre 2,0 e 5,0 a fixação é devida principalmente à precipitação de fósforo por íons de ferro e de aluminio que resultam na solução do solo apōs gradual dissolução dos óxidos destes elementos; b) na faixa de pH 4,5 a 7,5 os fosfatos são fixados na superficie das particu las de argila (sesquióxidos hidratados e argilas silicatadas); c) na faixa de pH 6,0 a 10,0 os fosfatos são precipitados por cátions divalentes presentes na solução do solo.

4.1.3. Influência do ferro e aluminio trocáveis e dos óxidos e hidróxidos de ferro e aluminio

Na Tabela 4, observa-se que o pH dos tratamentos com doses variāveis de vermiculita não acusa valores menores de 5,0, mas apresentando um crescente aumento dos valores a té atingir pH alcalino próximo a 8,0, o qual impossibilita consi derar um efeito importante dos ions de Fe e Al, insolúveis ne sa faixa de pH, na formação de fosfatos precipitados. Ainda,po de-se verificar uma elevação no teor de óxidos de ferro livre ao se adicionar o minério vermiculitico, que segundo o exposto, dentro da faixa de pH das amostras, seriam capazes de fixar ions fosfatos. O comportamento desses óxidos na fixação de fós foro, depende de sua mineralogia, a qual não foi determinada neste trabalho. Arlidge (1958) citado por VELAYUTHAM (1980) deu a seguinte ordem decrescente à capacidade dos óxidos de 
ferro para reagir com fosfato, determinada com raio-X: gel de óxido férrico = lepidocrocita = goetita e hematita.

Inúmeros pesquisadores, KITTRICK e JACKSON (1955), BACHE (1964), HSU (1964), tem salientado a relevante participa ção dos óxidos e hidróxidos de ferro e aluminio na fixação de fósforo.

HSU (1965), conclui, que em solos ligeiramente àcidos a reatividade desses hidróxidos e óxidos pode ultrapassar em muito, as atividades dos ions de aluminio e de ferro em solução liberados dos minerais do solo a pH menores de 5 e pro vocar o processo de sorção do ion fosfato. Considera ele, a ad sorção de fosfato por hidróxidos de aluminio ou de ferro, como um caso especial de precipitação. O cátion metālico permanece como constituinte na fase original e reage com os ions fosfa tos por residuos de forças nas superficies das particulas.

4.1.4. Influēncia do cālcio e magnésio trocáveis

No caso do $\mathrm{Ca}$ e $\mathrm{Mg}$, verifica-se nos dados da Tabela 4 , que houve um aumento na concentração de Mg nos trata mentos com vermiculita até atingir teores próximos a 15 e mg/100 g nas amostras. Similar aumento crescente acontece pa ra o cālcio no solo Paredão Vermelho, que chega a atingir teo- 
res de $0,83 \mathrm{e} . \mathrm{mg} / 100 \mathrm{~g}$, mas para o solo Quebra Dente, por efe $\underline{j}$ to de diluição observa-se un decréscimo na concentração.

O efeito dos cátions divalentes na fixação de fosfatos tem sido destacado por muitos pesquisadores devido a esses elementos formarem compostos de solubilidade variável com o fósforo.

PISSARIDES et alii (1963), verificaram que a satü ração das argilas com cátions divalentes aumentou a adsorção de fósforo quando comparada com a de cátions monovalentes. No ensaio, encontrou-se correlações positivas e altamente signifi cativas, entre os teores de magnésio e cālcio e a porcentagem de fósforo fixado pelos solos. Somente não foi encontrado correlação significativa entre o teor de cálcio do solo Quebra Dente e sua porcentagem de fósforo fixado.

Ao se comparar, os resultados da anālise química das amostras com a porcentagem de fósforo fixado pelos solos, pode-se considerar que possivelmente a fixação do fósforo foi causada devido ã precipitação do ion fosfato pelo cālcio e pe 10 magnésio, com teores relativamente altos, principalmente 0 magnésio, numa faixa do pH favorāvel à precipitação do ion fos fato por eles. 
De acordo com CHANG e JACKSON (1957), nos solos alcalinos e calcários, embora os compostos de ferro e aluminio sejam tambēm responsāveis por a lguma retenção de fósforo, este fenōmeno ē atribuido principalmente à precipitação do fósforo pelos compostos de cālcio.

LINDSAY et alii (1962), apontam que o fosfato aplicado em solos com alto teor de $\mathrm{Ca}^{++}$e em solos alcalinos precipita-se usualmente como fosfato bicálcico bihidratado $\left(\mathrm{CaHPO}_{4} \cdot 2 \mathrm{H}_{2} \mathrm{O}\right)$ e/ou fosfato octocálcico $\left(\mathrm{Ca}_{4} \mathrm{H}\left(\mathrm{PO}_{4}\right)_{3} \cdot 3 \mathrm{H}_{2} \mathrm{O}\right)$.

Segundo RACZ e SOPER (1967), o magnësio tambēm reage com o fosfato adicionado aos solos, formando fosfato bimagnésico trihidratado $\left(\mathrm{MgHPO}_{4} \cdot 3 \mathrm{H}_{2} \mathrm{O}\right)$ elou fosfato bimagnésico, que por dissolução forma o fosfato trimagnésico menos solúvel em àgua.

KLO e MIKKELSEN (1979) encontraram que a existên cia de $\mathrm{Mg}^{++}$na solução do solo tem efeito importante na fixação de fósforo devido à precipitação de fosfato octomagnésico $\left(\mathrm{Mg}_{8} \mathrm{H}_{2}\left(\mathrm{PO}_{4}\right)_{6}\right)$ e/ou fosfato trimagnésico $\left(\mathrm{Mg}_{3}\left(\mathrm{PO}_{4}\right)_{2}\right)$, os quais são estāveis em solos com elevado pH e altos teores de Mg. Concluiram os autores, cue a relação molar P/Mg quando igual ou menor que 2:1, tem um maior efeito na fixação. 
4.1.5. Influência da capacidade de troca de cātions e da porcentagem de saturação de bases

0 efeito da capacidade de troca de cátions (CTC) e da porcentagem de saturação de bases ( $V \%$ ) sobre a porcentagem do fósforo fixado pelos solos, revelando correlações positivas altamente significativas, pode ser explicado sobre o fato desses fatores serem dependentes nos tratamentos, do aumento em teor de argila vermiculita adicionada, contendo altos teores de cātions divalentes trocáveis.

\subsubsection{Influência do teor de areia}

o teor de areia total influenciou significativamente a capacidade de fixação do fōsforo pelas amostras, apresentando correlações negativas. Este resultado é consequẽncia da adição da vermiculita, ao se diluir o elevado conteúdo inicial de areia dos solos e aumentar o teor de argila, segundo o apresentado na granulometria das amostras na Tabela 3 . O efeito mais ativo da fração fina do solo sobre a fração grossa, tem sido mostrado por muitos pesquisadores. SA Jr. et alii (1968), determinaram a adsorção mäxima de fösforo em 17 solos de per. nambuco, concluindo que os solos de textura arenosa apresentaram menor adsorção que aqueles de textura argilosa. 


\subsection{Efeito na fixação de fōsforo causado. por doses crescen- tes de minērio caulinitico nas amostras de terra dos solos Paredão Vermelho e Quebra Dente.}

As médias das quantidades de fösforo fixado pelas amostras com teores variāveis de minērio caulinitico, expressas em ppm e suas respectivas porcentagens, bem como os valores das diferenças minimas significativas do teste de Tukey, estão contidas nas Tabelas 11 e 12 .

Os resultados apresentados na Tabela 11 , revelam um acrēscimo da capacidade de fixação de fōsforo pelas amostras do solo Paredão Vermelho quando o teor do minério aumentou. observou-se que a quantidade de fósforo fixado, aumentou tanto em valores absolutos (ppm de P) quanto em valores relativos (\% de P fixado). Na Tabela 12, observa-se um efeito oposto nas amostras do solo Quebra Dente, onde houve um decréscimo na quantida de de fósforo fixado, tanto em valores absolutos (ppm de P fixa do) quanto em valores relativos ( $\%$ de P fixado).

A anālise de variāncia, apresentada na Tabela 13 , revelou um efeito significativo do teor de minério adicionado, do tempo de reação e da dose de fosfato sobre a porcentagem de fósforo fixado.Devido ao fato das interações ter sido significa tivas, efetuou-se o desdobramento das mesmas, indicando-se as diferenças minimas significativas fornecidas pelo teste de Tukey. 


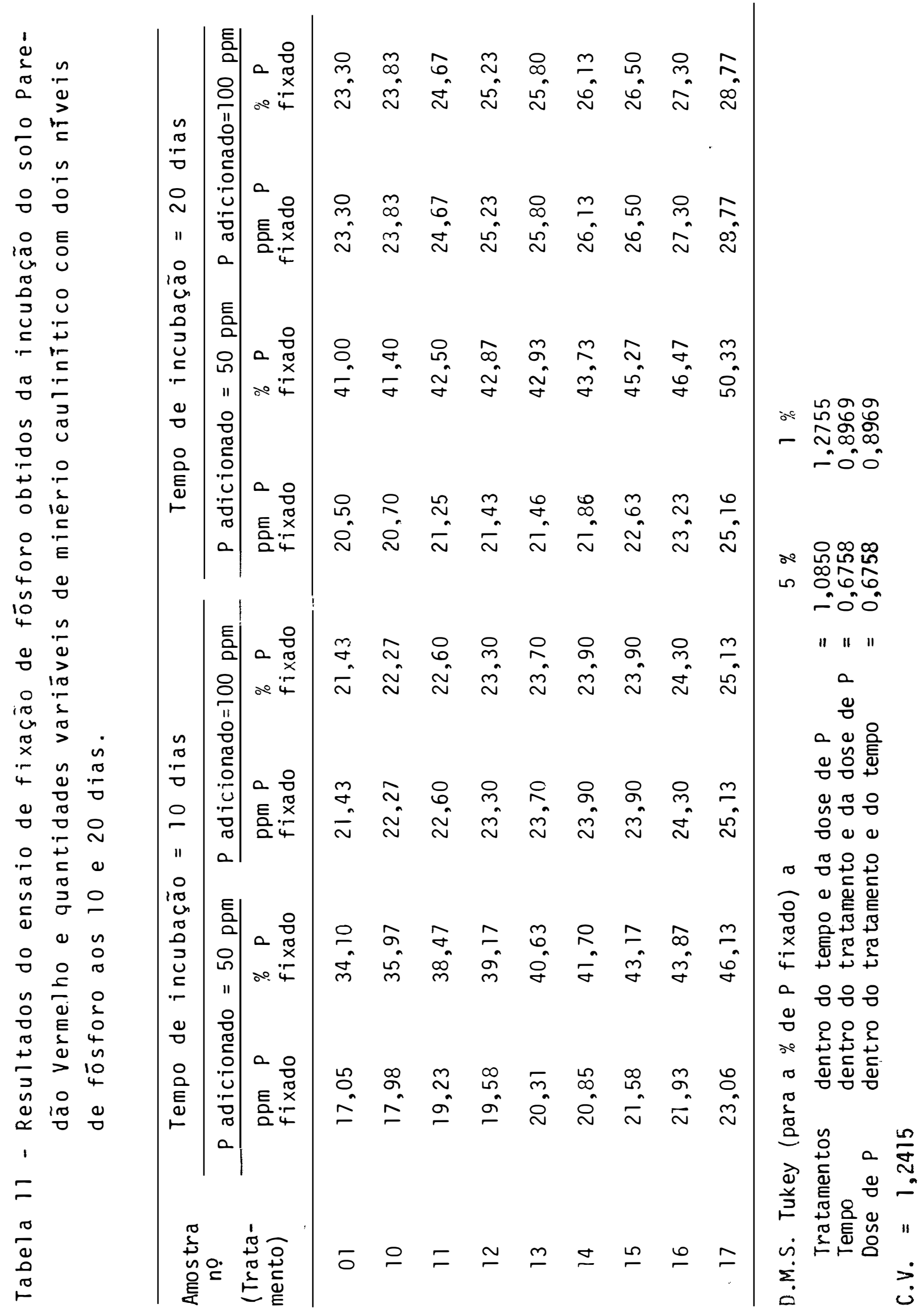


58.

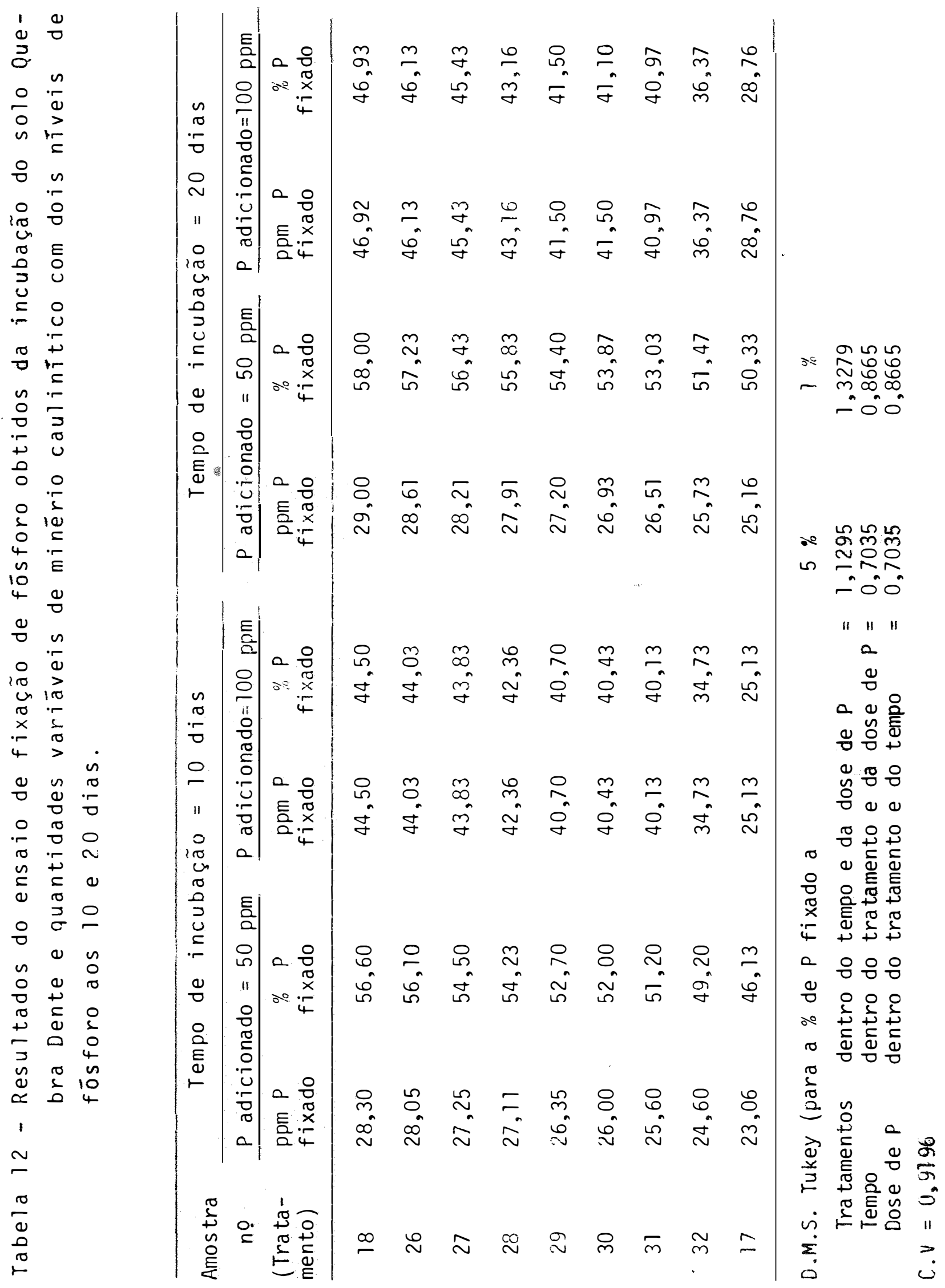


Tabela 13 - Anālise de variância para a porcentagem de $\mathrm{P}$ fixa do pelas amostras com doses crescentes de minërio caulinitico.

\begin{tabular}{|c|c|c|c|c|c|}
\hline \multirow{2}{*}{$\begin{array}{l}\text { Causas de } \\
\text { Variação }\end{array}$} & \multirow[t]{2}{*}{ G.L. } & \multicolumn{2}{|c|}{ Paredão Vermelho } & \multicolumn{2}{|c|}{ Quebra Dente } \\
\hline & & Q.M. & $F$ & Q.M. & F. \\
\hline Tempo (T) & 1 & 244,20 & $1421,17 * \star$ & 87,66 & $470,61 * *$ \\
\hline Dose de $P(P)$ & 1 & 8398,76 & $48877,80 * \star$ & 4682,07 & $25135,14 * \star$ \\
\hline $\begin{array}{l}\text { Dose de argi- } \\
\text { la }(A)\end{array}$ & 8 & 66,31 & $385,92 \star \star$ & 230,65 & $1238,24 * \star$ \\
\hline$T \times P$ & 1 & 12,95 & $75,37 * *$ & 0,98 & $5,26 * \star$ \\
\hline$T \times A$ & 8 & 1,75 & $10,19 * \star$ & 2,14 & $11,50 * *$ \\
\hline$P \times A$ & 8 & 11,40 & $66,38 * \star$ & 31,44 & $168,77 * \star$ \\
\hline$T \times P \times A$ & 8 & 3,05 & $17,74 * \star$ & 0,51 & $2,72 * *$ \\
\hline Resỉduo & 72 & 0,1718 & & 0,1862 & \\
\hline Total & 107 & & & & \\
\hline * - signif & icativ & a $5 \%$ & & & \\
\hline$\star \star-\operatorname{signif}$ & icativ & a $1 \%$ & & & \\
\hline
\end{tabular}

Confrontando os teores de fósforo fixados pelos solos com os fixados pelo minério puro, verifica-se que o solo Quebra Dente apresenta maior poder de fixação e que o solo Paredão Vermelho possui uma menor capacidade. No entanto, as amostras que receberam as maiores doses de caulinita apresenta 
60.

ram valores próximos ao do minério puro, mesmo produzindo adição da argila efeitos inversos nos dois solos.

As ilustrações gráficas dos tratamentos com os solos Paredão Vermelho e Quebra Dente são mostradas pelas Figu ras 7 e 8 , onde as porcentagens de fósforo fixado em função do teor de minério caulinitíco aplicado estão representadas pelas curvas de maior significāncia, sendo as equações de regressão de terceiro grau com altos valores para $R^{2}$.

As curvas das Figuras 7 e 8 , mostram um comporta mento semelhante dentro do mesmo solo quando submetido aos diferentes tratamentos. Comparando-as entre os solos, revelam um efeito oposto, positivo para o Paredão Vermelho e negativas pa ra o Quebra Dente.

4.2.1. Influência das características edáficas das amostras

A influēncia da argila caulinita na fixação de fósforo tem sido estudada por vārios pesquisadores. Midgley (1940), Raychaudhuri e Nukherjee (1941), citados por VELAYUTHAM (1980), consideram que a caulinita em condições naturais fixa pouco fosfato, mas quando a caulinita foi moida em moinhos de bola, STOUT (1939) e PERKINS (1948) encontraram alta fixação, Schuffelem e Schuylenborgh (1951), citados pelo mesmo autor ve 


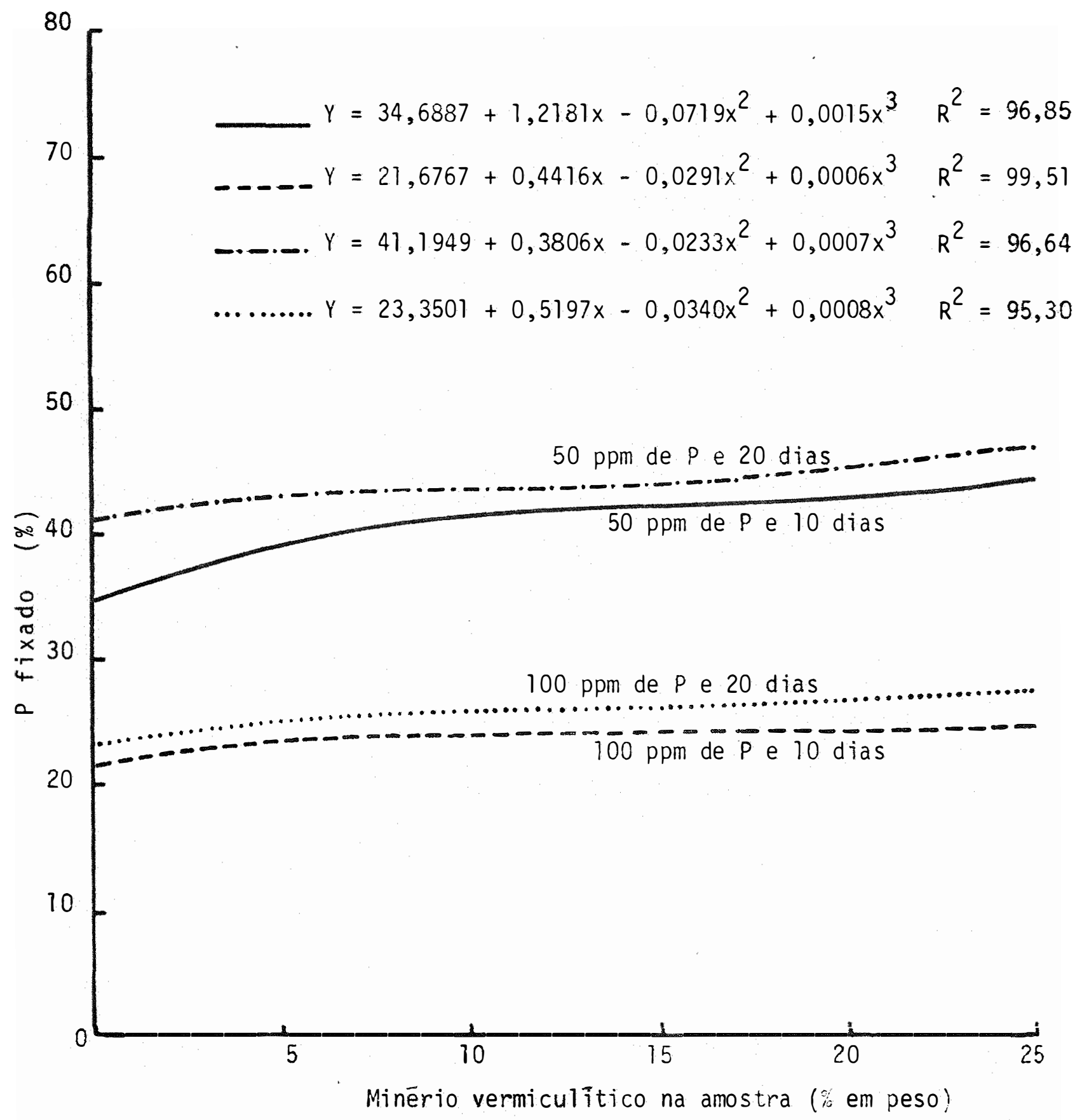

Figura 7 - Curvas de fixação de $P$ para 0 solo Paredão Vermelho com doses variāveis de minērio caulinitico. 


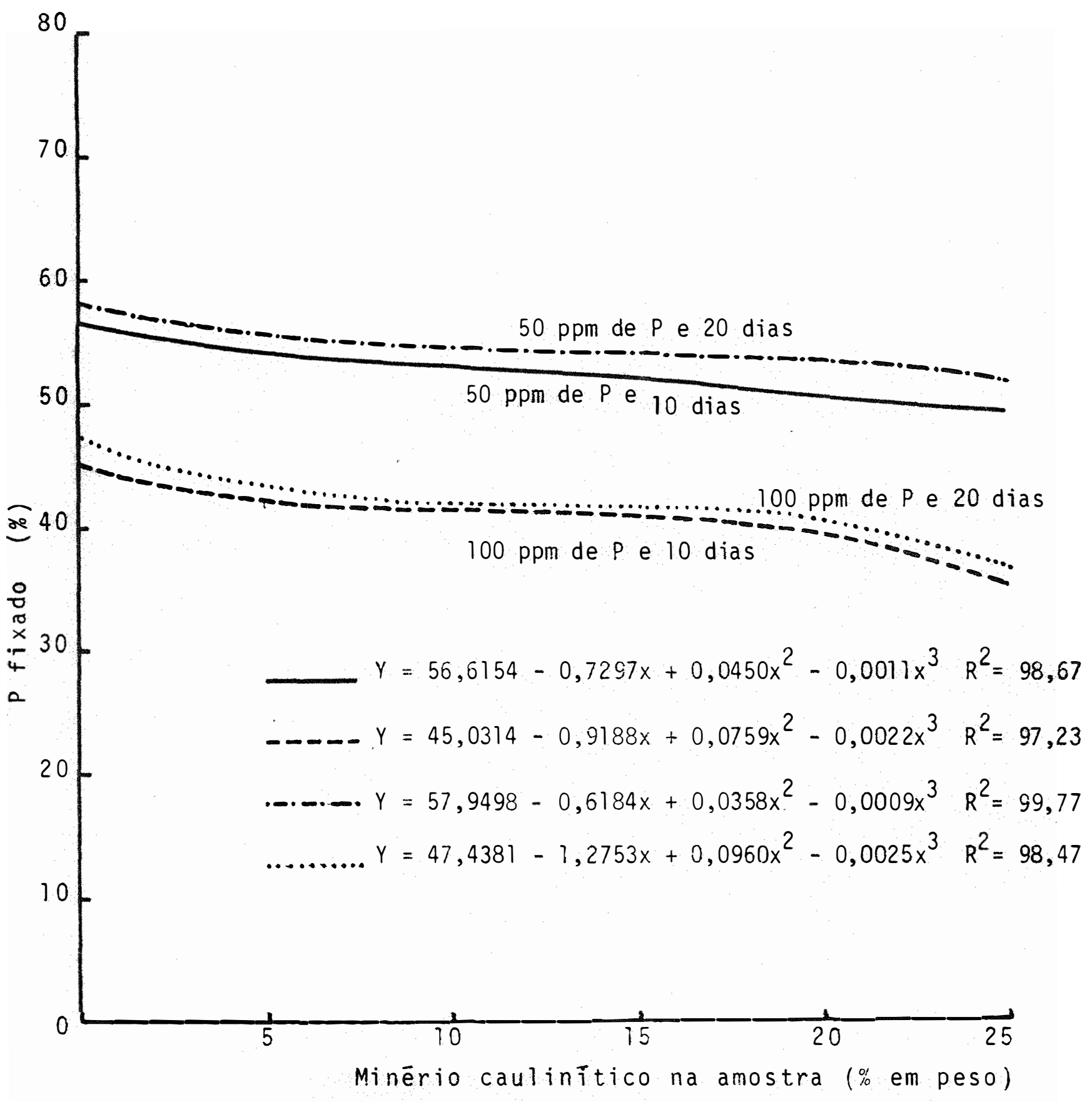

Figura 8 - Curvas de fixação de P para o solo Quebra Dente com doses variāveis de minério caulinitico. 
rificaram que a moagem causou quebras dos cristais de caulinita, expondo as arestas quebradas de $\mathrm{Al}_{2} \mathrm{O}_{3}, \mathrm{SiO}_{2}$ e $\mathrm{H}_{2} \mathrm{O}$.

MURPHY (1939), pesquisando sobre o papel da cauIinita na fixação do fosfato concluiu que a caulinita quando finamente moida tem uma grande capacidade para fixar fosfatose que a concentração do ion hidrogênio constitui um importante fator no processo de fixação. A fixação decresce quando a concentração do ion $\mathrm{OH}^{-}$aumenta. Nos valores altos de pH o complexo caulinitico é incapaz de adsorver fosfatos o que é oposto à adsorção de cātions, a cual se incrementa com um aumento da concentração de ions $\mathrm{OH}^{-}$

Foram encontradas correlações positivas e alta mente significativas, entre a porcentagem de fósforo fixado pe 10 solo Paredão Vermelho com doses crescentes de caulinita e o teor de argila, aluminio trocāvel e a CTC das amostras. Com respeito ao pHe a $V \%$ as correlações encontradas foram negati vas, e para o ca e o Mg trocāvel não houve correlação significativa. Estes resultados podem ser considerados concordantes com a conclusão apresentada por MURPhy (1939), previamente cita da. Considera-se que houve mais caulinita carregada positiva mente naquelas amostras com maior teor do minērio e com pH mais baixo. Os menores valores do pH tambēm favoreceram a fixação do fösforo pelo aluminio trocável e pelos ōxidos de ferro livre, mas impedem a disponibilidade de cālcio e magnésio trocā- 
vel, conforme as conclusões apontadas por Bradley (1935), cita do por RODRIGUES (1980), mencionadasanteriormente.

Para o solo Quebra Dente, a diminuição de sua cá pacidade de fixação de fósforo com a adição do minério caulinị tico, possivelmente possa ser explicado em termos da diluição dos constituintes do solo original. Como pode ser visto nas Ta belas 3 e 4 , as caracteristicas físicas e quimicas dos trata mentos deste solo como as doses de caulinita são bastante seme Thantes às do solo Paredão Vermelho, apesar disto, o efeito da argila é contrārio nos dois solos. Consequentemente, as correlações obtidas entre a porcentagem de fósforo fixado pelo so 10 Quebra Dente com doses crescentes do minërio e o teor de a gila, aluminio trocável e CTC foram negativas, sendo que para $\mathrm{pH}$ e $\mathrm{V} \%$ foram positivas.

A constituição mineralógica das argilas silicata das do solo Quebra Dente, apresentada na Tabela 7 , mostra a presença nesse solo das argilas vermiculita e ilita, com grade $2: 1$, e de caulinita com grade 1:1. A adição do minério caulinitico provocou uma diluição no teor da vermiculita e da ili ta nas amostras do solo, consideradas com grande poder de fixa ção do ion fosfato. A importāncia das argilas com grade 2:1 tem sido constatada por COLE e JACKSON (1960) que apontam que entre os argilo-minerais, os do grupo da vermiculita parecem 
apresentar maior poder de fixação, e por SUBRAMANIAN (1965), que pesquisando com argilas puras, determinou uma maior capac $\underline{i}$ dade de fixação do fósforo pela ilita que pela caulinita.

\subsection{Efeito do tempo de contato entre o ion fosfato e. o so- lo na fixação de fósforo.}

Os dados apresentados nas Tabelas $3,9,10$ e 11 mostram que a fixação de fósforo cresce com o aumento do tempo de contato entre as amostras de solo e do ion fosfato adicionado, tanto em valores absolutos (ppm de $p$ fixado) quanto em valo res relativos (\% de p fixado).

A anālise estatistica revelou para todos os trata mentos um Teste $F$ altamente significativo, indicando a influēncia positiva do perīodo de reação solo x fōsforo no processo de fixạ̧ão.

Verifica-se, que se estabelecer um indice 100 para as quantidades de fósforo fixadas aos 20 dias de incubação, que aos 10 dias já tinha sido fixada, aproximadamente, mais de $90 \%$ da quantidade final. Esses valores relativos para todos os tratamentos são apresentados na Tabela 14 . 

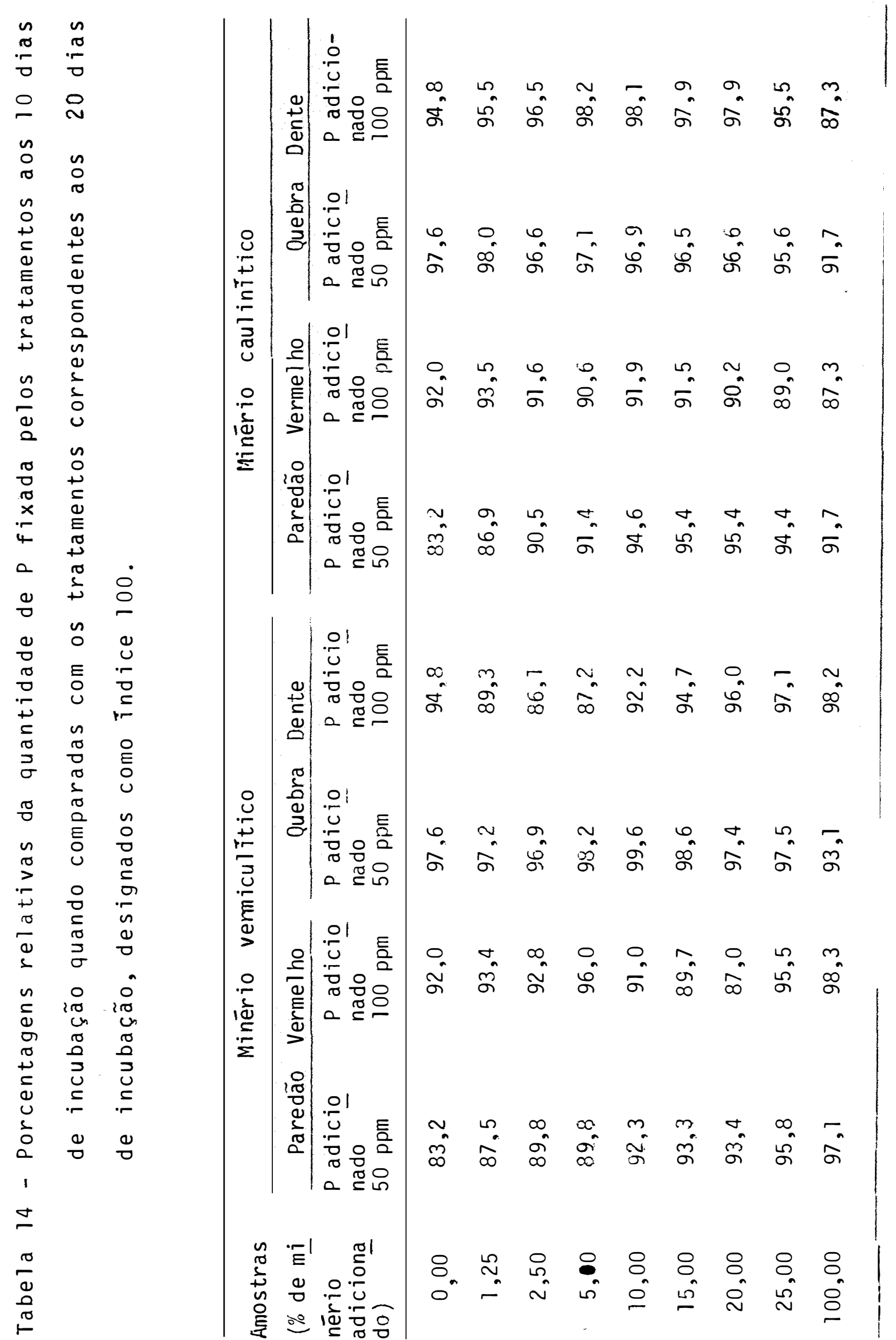
As Figuras $5,6,7$ e 8 , representando as porcen tagens de fósforo fixado pelos solos com teores variāveis de minērios, nas duas doses de fósforo e nos dois tempos de incubação, ilustram a proximidade das curvas dos tratamentos incu bados em tempos diferentes com uma mesma dosagem de fósforo, indicando a pouca variação na porcentagem de fósforo fixado no periodo de 10 e 20 dias, mas sempre mostrando que a curva de maior fixação corresponde aos tratamentos com 20 dias de incubação.

os resultados obtidos concordam com outros trabalhos que estudam os fatores que influenciam a fixação, onde se demonstra que a maior parte do fósforo adicionado foi fixa do em poucas horas, podendo esta continuar por um ano ou mais.

Estudando a fixação do fósforo em quatro solos dos Estados Unidos a intervalos de $2,10,40$ e 80 dias, Heck (1934), citado por GHANI e ISLAN (1946), encontrou que a maior intensidade de fixação aconteceu logo após o contato solo $x$ fósforo. Entre o segundo e o dēcimo dia de reação, a fixação estabilizou, descrevendo virtualmente uma linha reta.

LOURENÇO (1973) concluiu que a adsorção do fósforo aumenta com o tempo de reação. Em tempos muito curtos ( 5 a 10 minutos), a adsorção foi surpreendentemente a 1 ta. 0 tem- 
po de 24 horas parece ser suficiente para estudos de adsorção de "quase-equilibrio". O autor observou, a inda, três regiões de velocidade de adsorção: uma que se completou até 2 horas, uma segunda de 2 a 24 horas e a terceira em tempos superiores a 24 horas. Admite, que as reações mais lentas envolvem a pene tração do ion fosfato em regiões menos acessiveis da rede cris talina.

Para explicar a maior intensidade da fixação de fósforo nas primeiras horas e dias de contato do solo como ion fosfato, tem sido oferecidas vārias considerações.

Pesquisando a reação do ion fosfato com diferen tes tipos de argila e hidröxidos de ferro e aluminio, HASEMAN et alij. (1950), sugerem que o periodo de rāpida fixação resu ta da reação do ion fosfato com o aluminio elou o ferro prontamente disponíveis; uma fixação lenta é consequência da reação do ion fosfato com o aluminio elou o ferro liberados quan do hä decomposição de compostos do solo.

Quanto ao mecanismo de adsorção do fosfato pela caulinita, gibsita e pseudobohemita, MULJADI et alij (1961), consideram que existem diferentes regiões responsāveis pela fixação do fósforo, que atuam em tempos diferentes: os àto mos de aluminio localizados nas arestas dos cristais, e aque- 
las onde ocorre a penetração do fosfato em alguma parte amorfa da superfície dos cristais, e que corresponde à parte linear da i soterma de adsorção.

\subsection{Efeito na fixação de fósforo causado pela quantidade de fosfato aplicado}

Os resultados deste trabalho, contidos nas Tabelas 8, 9, 10 e 11 , mostram que com o acréscimo das doses de fósforo adicionadas ao solo, a fixação ałmenta em valores abso lutos (ppm de $P$ fixado) mas diminui em valores relativos (\% de P fixado).

Ao se estudar o efeito das doses de fósforo apli cadas, a anālise estatística revelou um efeito altamente signi ficativo, indicando sua influēncia no fenōmeno da fixação.

A observação das Figuras $5,6,7$ e 8 , referentes as porcentagens do fósforo fixado pelas amostras em função dos teores variāveis de minērio, com as doses de 50 e 100 ppm de P, permite inferir dentro de um mesmo tempo de incubação, que as curvas que representam as doses menores apresentam sempre maio res porcentagens de fixação, o que indica uma tendēncia de saturação dos solos com a maior dose de fósforo (100 ppm). 
os resultados observados neste trabalho coincidem com aqueles obtidos por LARSEN (1967), ANASTACIO (1968), LOURENÇO (1973) E RESENDE (1974).

Para explicar a influência da dosagem de fósforo no fenōmeno de fixação, LARSEN (1967), tem sugerido que se existe pouco fósforo no solo, ele será fortemente adsorvido e a solução apresentará baixa concentração; ao se adicionar mais fósforo haverá uma elevação na concentração da solução a tē atingir um nivel de equilibrio correspondente ao produto de solubilidade de algum mineral fosfatado; com a adição de mais fósforo, a concentração aumentarà acima dn valor em equilïbrio, mas, com o tempo, esta concentração diminuirá até alcançar um novo equilibrio.

ANASTACIO (1968), estudando a fixação de fōsforo nos solos brasileiros, com doses de fósforo aplicadas entre 0 e $400 \mathrm{ppm}$, observou que todos os solos diminuiram a por centagem do fósforo fixado quando se adicionava uma dose acima de 50 ppm, embora, houvesse um aumento dos ppm de fósforo retidos.

RESENDE (1974), conciui que para um mesmo perīo do de 5 dias ao se aumentar a dosagem para 200 ppm de fósforo, a quantidade de ppm de $P$ fixado por solos da Bahia e Sergipe aumenta, mas é observada uma diminuição da porcentagem fixada. 
71.

5. CONCLUSOES

Dos resultados obtidos neste trabalho, foi possivel concluir que:

1. O minērio vermiculitico e o solo Quebra Dente, com argilas de grade cristalina 2:1, fixaram respectivamente, maior quantidade de fósforo do que o minério caulinîtico e que o solo Paredão Vermelho com argila de grade $1: 1$.

2. O solo Paredão Vermelho (Latossol) e o Quebra Dente (Podzólico), quando receberam as maiores dosagens de minērio vermiculitico (25\%), mostraram uma tendēncia de uniformização na fixação de fósforo, aproximando-se à quantidade fí xada pelo minērio puro. 
72.

3. O minério caulinitico quando adicionado às amostras dos solos, apresentou um comportamen to diferente: aumentou a fixação de fósforo no solo Paredão Vermelho (Latossol) e a reduziu no solo Quebra Dente (Podzōlico).

4. Mais de oitenta por cento do fósforo foi fixa do nos 10 dias de incubação quando comparados com as porcentagens fixadas aos 20 dias, inde pendentemente do teor de fósforo adicionado e da porcentagem de argila presente no solo.

5. Aumentando a dose de fósforo de 50 ppm para 100 ppm, para um mesmo tempo de incubação,cres ceu a quantidade de fósforo fixado em valores absolutos (ppm), mas diminuiu em valores rela tivos (porcentagem). 
73.

6. LITERATURA CITADA

ANASTACI0, M. de L.A., 1968. Fixação de fósforo nos solos bra sileiros. Boletim Técnico da Equipe de Pedologia e Fertilidade do Solo. Rio de Janeiro, nọ 4, 14 p.

BACHE, B.W., 1964. Aluminum and iron phosphates studies relating to soil. Journal of Soil science. Oxford, 15 (1): 110116.

BitTenCOURT, V.C. e E. ZAMBELlo, 1973. Comportamento do fósfo ro em solos tropicais. I. Isotermas de Adsorção. Boletim. BC-012. CENA. Piracicaba. 24 p.

BLANCHET, R., 1959. A phosphate sorption for soils. Annales. Agronomiques. Paris, 10 A: 121-154. 
BOHN, H.L. e M. PEECH, 1969. Phosphato iron (III) and phosphato aluminum complexes in dilute solutions. Proceedings. of Soil Science Society of America. Madison, 33 (6): 837 876.

BRADFIELD, R.; G. SCARSETH e J.G. STEELE, 1935. Factors affec ting the retention of phosphate by clays. In: 30 International Congress of Soil Science. Oxford, v. 1. p. 74-75.

BROMFIELD, S.M., 1964. Relative contribution of iron and alu minum in phosphate sorption by acid surface soils. Nature. London, 201: $321-322$.

CABALA, R.P. e H.W. FASSBENDER, 1971. Efecto del encalado en las formas y disponibilidad de fosfatos en suelos de la re giōn cacaotera de Bahia, Brasil. Turrialba, 21: 38-46.

CAVALCANTI, F.A., 1974. Alguns aspectos da fixação do fósforo por solos da Região de Piracicaba. Piracicaba, ESALQ/USP, 62 p. (Dissertação de Mestrado).

CALVERT, D.V.; H.F. MASSEY E W.A. SEAY, 1960. The effect of exchangeable calcium on the retention of phosphorus by clay fractions of soils of the Memphis Catena. Proceedings of Soil Science of America_. Madion, 24: 333-335. 
CATANI, R.A., 1947. Contribuição ao estudo dos fosfatos, sua dosagem, extração e distribuição nos solos do Estado de São Paulo. Piracicaba, ESALQ USP, $65 \mathrm{p}$. (Tese de Doutoramento).

CATANI, R.A. e A.0. JACINTHO, 1974. Avaliação da fertiridade. do solo; Métodos de análise. Piracicaba, Livroceres $61 \mathrm{p}$.

CATANI, R.A. e D. PELLEGRINO, 1957. A fixação de fōsforo em alguns solos do Estado de São Paulo, estudada com o auxilio do fósforo radioativo ${ }^{32} \mathrm{P}_{15}$. Revista da Agricultura... Pira cicaba, $32(4): 237-252$.

CATANI, R.A. e D. PELLEGRINo, 1960. Avaliação da capacidade de fixação de fósforo, pelo solo. Anais da $\underline{E} \cdot \underline{S} . \underline{A}$. "Luiz de Queiroz". Piracicada, 17 (271): 19-28.

CATANI, R.A. e N.A. GLORIA, 1964. Evaluation of the capacity of phosphoro fixation by the soils through the isotopic ex-

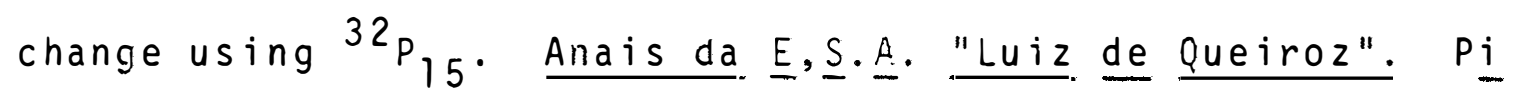
racicaba, 21: 230-237.

CHANG, S.C. e M.L. JACKSON, 1957. Solubility product of iron phosphate. Proceedings of Soil Science Society of America. Madison, 21: 265-269. 
CHANG, S.C. E K.K. CHU, 1961. The fato of soluble phosphates applied to soils. Journal of Soil Science. Oxford, 12: $286-293$.

CLARK, J.S. e M. PEECH, 1960. Influence of neutral salts on the phosphate ion concentration in soil solution. Proceedings of Soil Science Society of America. Madison, 24: 346348 .

COLE, C.V. e M.L. JACKSON, 1950. Solubility equilibrium cons tant of dinidroxy-phosphate relating to a mechanism of phos phate fixation in soils. Proceedings of Soil Science Society of America. Madison, 15: 84-88.

COLLEMAN, R., 1944. The mechanism of phosphate fixation by montmorillonitic and kaolinitic clays. Proceedings of Soil Science Society of America. Madison, 9: 72-78.

DABIN, B., 1970. Méthode d'étude de $7 a$ fixation du phosphore sur les sols tropicaux. Coton et fibres tropicales. Paris, 25 (3): $289-310$.

DAVIS, L.F., 1935. Sorption of phosphate by non calcareous Hawaitan soils. Soil Science. Baltimore, 40: 129-158. 
DEAN, L.A., 1949. Fixation of soil phosphorus. Advances in Agronomy. Palo Alto, 1: $391-411$.

DE DATTA, S.K., 1961. Adsorption of phosphate ion by hydro gen derivate of Indian montmorillonite (Kashmir bendorite). Soil Science. Baltimore, 92: 117-119.

DE, S.K.; R.L. FOX E G.D. SHERMAN, 1963. Availability of fertilizer phosphorus in three latosols of Hawai. Agronomy Journal. Madison, 55 (4): $311-313$.

DUNBAR, A.D. e D.E. BAKER, 1965. Use of isotopic dilution in a study of inorganic phosphorus fractions from differents soils. Proceedings of Soil science Society of America. Madison 29: 259-262.

ELLIS, R. e E. TRUOG, 1955. Phosphate fixation by montmorillonite. Proceedings of Soil Science Society of America. Ma dison, $19(4): 451-454$.

FASSBENDER, H.W., 1966. La adsorciōn de fosfatos en suelos fuertemente àcidos y su evoluciōn usando la isoterma de Lang muir. Fitotecnia Latinoamericana. San José, $\underline{3}(1 / 2)$ : $203-$ 216. 
FASSBENDER, H.W., 1969a. Retenciōn y transformaciōn de fosfa tos en ocho latossolos de la Amazoniadel Brasil. Fitotec nia Latinoamericana. San José, 6 (1): 115-126.

FASSBENDER, H.W., 1969b. Estudio del fósforo en suelos de América Central. IV. Capacidad de fijación de fósforo y su relaciōn com caracteristicas edāficas. Turrialba, 19: 497505 .

FRANKLIN, W.T. e H.M. RETSENAUER, 1960. Chemical characteris tics of soil related to phosphorus fixation and availability. Soil Science. Baltimore, 90: 192-200.

GHANI, M.0. e M.A. ISLAM, 1946. Phosphate fixation in acid soils and its mecanism. Soil Science. Baltimore, 62: 293306 .

GUTNIK, V.; J. BALCAR; H. BEHRENS e E. ACEVEDO, 1967. Influen cia del pH sobre la fijaciōn del fósforo en suelos derivados de cenizas volcānicas. Agricultura Técnica. Santiago de Chile, 24 (4): 141-143.

HALL, J.K. e D.E. BAKER, 1971. Phosphorus fixation by montmorillonitic and vermiculite clays as influenced by $\mathrm{pH}$ and saluble aluminum. Proceedings of Soil Science Society of America. Madison, 35: 876-881. 
HASEMAN, J.F.; E.H. BROVIN E C.D. WIITT, 1950. Some reactions of phosphate with clays and hidrous oxides of iron and aluminum. Soil science. Baltimore, 70: 257-71.

HEMWALL, J.B., 1957. The fixation of phosphorus by soi.ls. Advances in Agronomy. Palo Alto, 9: 95-111.

HIBBARD, P.L., 1935. Factors influencing phosphate fixations in soils. Proceedings of Soil Science Society of America. Madison, 28: $337-358$.

HSU, P.H., 1964. Adsorption of phosphate by aluminum and iron in soils. Proceedings of Soil Science Society of America. Madison, 28 (4): 474-478.

HSU, P.H., 1965. Fixation of phosphate by aluminum and iron in acid soils. Soil Science. Baltimore, 99 (6): 398-402.

HSU, P.H. e M.L. JACKSON, 1960. Inorganic phosphate transfor mations by chemical weathering in soils as influenced by $\mathrm{pH}$. Soil Science, Baltimore, 90: 16-24.

JACKSON, M.L., 1956. Soils chemical analysis: advanced course. Madison, Wis., Univ. of Wis., 991 p. 
KARDOS, L.T., 1969. Soil fixation of plant nutrients. In: BEAR, F.E. ed. Chemistry of the soil.2. ed. New York, Van Nostrand, p. 369-394.

KILMER, V.J. e L.T. ALEXANDER, 1949. Method of making mecha nical analysis of soils. Soil science. Baltimore, 68: 1526.

KITSON, R.E. e M.E. MELLONS, 1944. Colorimetric determination of phosphorus as molybdivanadophosphoric acids. Industrial and Engineering Chemistry. Washington, 16: 379 .

KITTRICK, J.A. e M.L. JACKSON, 1955. Electron microscope observations of the reactions of phosphate with minerals, lea ding to a unified theory of phosphate fixation in soils. Journal of Soil science. Oxford, I (1): 81-90.

KITTRICK, J.A. e M.L. JACKSON, 1955. Rate of phosphate reaction with soils minerals and electron microscope observations on the reaction mecanism. Proceedings of Soil science Society of America. Madison, 19: 292-295.

KUO, S. e D.S. MIKKELSEN, 1979. Effect of magnesium on phospha te adsorption by calcium carbonate. Soil science. Baltimore, $127(2): 65-73$. 
KUO, S. e E.G. LOTSE, 1972. Kinetics of phosphate adsorption by calcium carbonate and Ca-Kaolinite. Proceedings of Soil. Science Society of America. Madison, 36: 725-729.

KURTZ, L.T., 1953. Inorganic phosphorus in acid and neutral soils. In: PIERRE, W.H. e A.G. NORMAN, ed. Soil and fertilizer phosphorus in crop nutrition. New York, Academic Press, p, 59-88.

LARSEN, S., 1967. Soil phosphorus. Advances in Agronomy. Pa= 10 Alto, 19: 151-210.

LARSEN, S.; D.J. PERTON E I. SVENSSON, 1963. Reaction between monocalcium phosphate and calcium carbonate. Nature. London, 197: $317-329$.

LEAL, J.R. e A.C. VELLOSO, 1973. Adsorção de fosfato em latos solos sob vegetação de cerrado. Pesquisa Agropecuāria Brasileira. Rio de Janeiro, 8: 81-88.

LEAL, J.R. e A.C. VELLOSO, 1973. Dessorção do fosfato adsorvi do em latossolos sob vegetação de cerrado. II. Reversibilida de da isoterma de adsorção de fosfato em reíação a pH da so lução de equilíbrio. Pesquisa Agropecuäria Brasileira. Rio de Janeiro, 8: 89-92. 
LINDSAY, W.L.; A.W. FRAZIER e H.F. STEPHENSON, 1962. Identification of reaction from phosphate fertilizer in soil. Proceedings of Soil Science Society of America. Madison, 26: $446-452$.

LINDSAY, W.L. e E.C. MORENo, 1960. Phosphate phase equilibria in soils. Proceedings of Soil Science Society of America. Madison, 24 (5): 117-182.

LOURENÇO, S., 1973. Adsorção e dessorção do fösforo em solos do Estado do Paranā. Piracicaba, ESALQ/USP, 69 p. (Tese de Doutoramento).

MALAVOLTA, E. e D. PELLEGRINO, 1954. Nota sobre algumas trans formaçöes de superfosfato radioativo em terra roxa. Revista. de Agricultura. Piracicaba, 29: 317-23.

MARSHALL, E.C., 1964. The physical chemistry and mineralogy. of soils. New York, John Wyley and Sons, $388 \mathrm{p}$.

MEHRA, O.P. E M.L. JACKSON, 1960. Iron oxide removel from soil and clay by dithionite citrate system buffered with sodium bicarbonate. In: Nath conf. on clays and clays minerals New York, Pergamon Press, p. 317-327. 
MELLO, F.A.F., 1970. Um método para avaliar a capacidade de fixação de fosfato pelo solo, empregando $0^{32} p_{15}$. Anais da $\underline{E} \cdot \underline{S} . \underline{A}$. "Luiz de Queiroz". Piracicaba, 27: 347-352.

MELLO, F.A.F.; M.O.C. BRASIL SOBRINHO; S. ARZOLLA; A. COBRA NETTO e R.I. SILVEIRA, 1972. Fertilidade do Solo. Piracicaba, ESALQ, Depto de Solos e Geologia, $197 \mathrm{p}$.

MOURA FILHO, W., 1970. Studies of a latosol roxo (Extrustox) in Brasil: Clay mineralogy, micromorfology, effect of ion rebase, and phosphate reaction. Raleigh, North Caroline, North Caroline State University (Ph.D. Thesis).

MULJADI, D.; A.M. POSNER E J.P. QUIRK, 1966. The mecanism of phosphate adsorption by kalinite, gibbsite and pseudo bohe mite. Journal of Soil science. Oxford, 17 (2): 212-247.

MURPHY, H.F., 1939. The role of kalinite in phosphate fixation. Hilgardia. Berkeley, 12 (5): 342-382.

NEVES, L.E., 1968. Estudo prātico de argila por difratometria de raio-x. Boletim Técnico da Petrobräs. Rio de Janeiro, 11 (1): 123-135. 
OLSEN, S.R., 1953. Phosphorus in alkaline and calcareous soils. Inorganic phosphorus in alkaline and calcareous soils. In: PIERRE, W.H. e A.G. NORMAN, ed. Soil fertilizer phosphorus in crop nutrition. New York, Academic Press, p. 89122.

OLSEN, S.R. e F.S.A. WATANABE, 1957. A method to determine a phosphorus adsorption maximum of soils measured by Langmuir isotherm. Proceedings of Soil science Society of America. Madison, 21 (2): 144-149.

PERKINS, A.T., 1948. Phosphate fixation by soil minerals. Proceedings of Soil Science Society of America. Madison, 13: $99-101$.

PISSARIDES, A.; J.W. STEWART E D.A. RENNIE, 1968. Influence of cation saturation on phosphorus adsorption by selected clay minerals. Canadian Journal of Soil Science. Ottawa, 48: $151-157$.

PRATT, P.F., 1966. Quimica do solo. Tradução. S.l., USAID/ Brasil, $88 \mathrm{p}$. 
RACZ, G.J. e R.J. SOPER, 1967. Reaction products of orthophos phates in soils containing varying amounts of.calcium and magnesium. Canadian Journal of Soil Science. Ottawa, 48: 265-269.

RAJAN, S.S. e R.L. FOX, 1972. Phosphate adsorption by soils. Influence of time and ionic enviroment on phosphate adsorp tion. Communications in Soil Science and Plant Analysis. New York, $\underline{3}(6): 493-504$.

RALTJE, W., 1960. On the natural conversion of calcium-bound phosphoric acid and aluminum and ferric-ironbound phosphoric acid in soil. Plant and Soil. The Hagne, 13: 159-165.

RANZANI, G.; 0. FREIRE e T. KINJ0, 1966. Carta de Solos do Municipio de Piracicaba. Piracicaba, Centro de Estudos de Solos da E.S.A. "Luiz de Queiroz", USP, 85 p.

RAVIKOVITCH, S., 1939. Influence of exchangeable cation on the availability of phosphate in soils. Soil science. Baltimore, 47: $357-366$.

REZENDE, J.0., 1974. Capacidade de fixação de fósforo por solos dos Estados da Bahia e Sergipe. Influēncia do pH e tempo de reação. Piracicaba, ESALQ/USP, 81 p. (Dissertação de Me trado). 
RODRIGUES, M.R., 1980. Fatores que afetam a fixação de fosfatos nos solos do Estado de São Paulo. Piracicaba, E.S.A. "Luiz de Queiroz"/USP, 58 p. (Dissertação de Mestrado).

SA JUNIOR, P.M.; F.I. GOMES e A.L. VASCONCELOS, 1968. Reten ção de fósforo em solos da zona da Mata de Pernambuco. Pesquisa Agropecuāria Brasileira. Rio de Janeiro, 3: 183-188.

SAINI, G.R., 1965. Phosphorus retention capacities of some New Brunswick soils and their relationship with soil proper ties. Canadian Journal of Soil Science. Ottawa, 45: 15-18.

SHERMAN, M.S., 1942. Colorimetric determination of phosphorus in soils. Industrial and Engineering Chemistry. Washington 14: 182 .

STOUT, P.R., 1939. Alterations in the crystal tructurs of clay minerals as a result of phosphate fixation. Proceedings of Soil Science Society of America. Madison, 4: 177-182.

STRONG, J. e G.J. RACZ, 1970. Reaction products of applied orthophosphate in some Manitoba soils as affected by soil calcium and magnesium content and time of incubation. Soil Science. Baltimore, 110: 258-262. 
SUBRAMANIAN, T.R., i965. Studies on the exchangeable phospho rus in soils and ciay minerals. Indian Journal of Agricuiture science. New Delhi, 35: is-84.

SYERS, J.K.; J.T. EVANS; J.D.H. WILLIANS E J.T. MURDOCK, 1971. Phosphate sorption parameters of representative soils from Rio Grande do Sul, Brasil. Soil Scierice. Baltimore, 112 (4): $267-275$.

TEIXEIRA MENDES, A.C., 1972. Identificação das argilas do soto por difração do raio-X. Piracicaba, ESALQ/USP, 34 p.

TISDALE, S.L. e W.L. NELSON, 1965. Soil Fertility and Fertilizers. New York, MacMillam, $430 \mathrm{p}$.

UDO, E.J. e F.0. UZU, 1972. Characteristics of phosphorus adsorption by som migeriam soils. Proceedings of Soil science Society of America. Madison, 36: 879-883.

VASCONCELLOS, C.A., 1973. Contribuição para o estudo de fósfọ ro em dois latossolos do Estado de Matl Grosso. Viçosa, UFV, 103 p. (Dissertação de Mestrado).

VELAYUTHAM, M., 1980. The problem of phosphate fixation by mi nerals and soil colloids. Phosphorus in agriculture. Paris, 77: $1-8$. 
VOLK, V.V. e E.0. MCLEAir, 1963. The fate of applied phosphorus in four Ohio soils. Proceedings of Soil science society of America. Madison, 27: 53-58.

WEISER, V.L. e M.C. FORD, 1933. Fixation and penetration of phosphates. Bulletim of Vermont Experimental Station . Bur lington (356).

WILD, A., 1950. The retention of phosphate by soil. A review Journal of Soil science. 0xford, 1: 221-38.

WILD, A., 1953. The effect of exchangeable cations on the re tention of phosphate by clay. Journal of Soil science. Oxford, $4: 72-85$.

WILLIANS, E.G., 1960. Some aspects of phosphate retention and availability in soils. In: Transactions of the 7 th. International Congress of Soil Science, Madison, v. 3, p.607-611. 